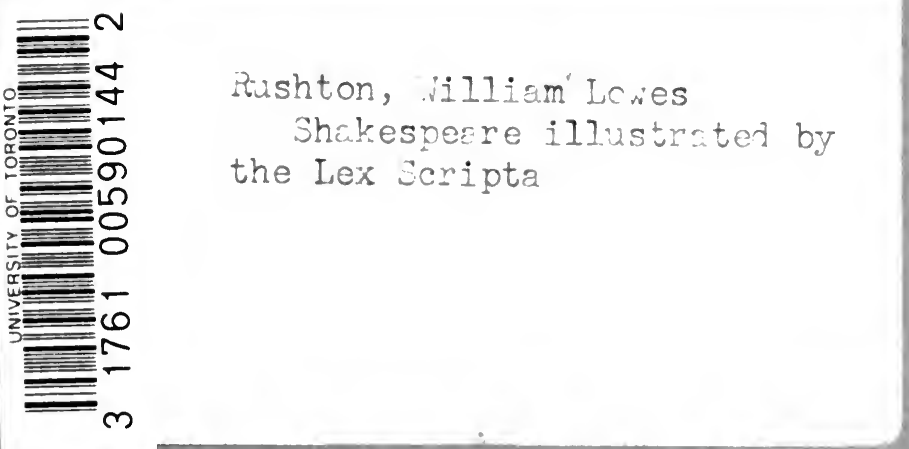

PR

3028

R78

1870

v. 1 


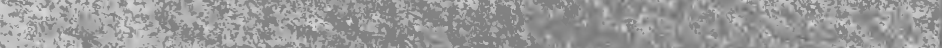
H.

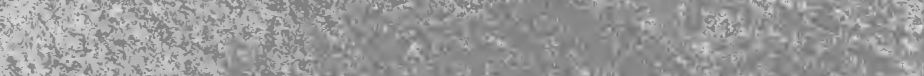

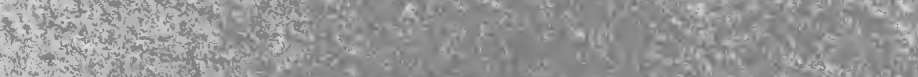

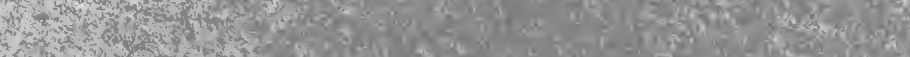

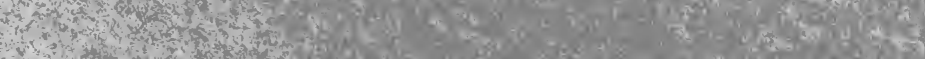

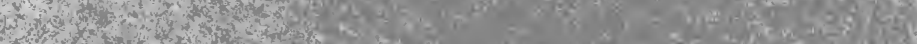

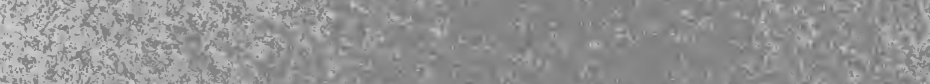

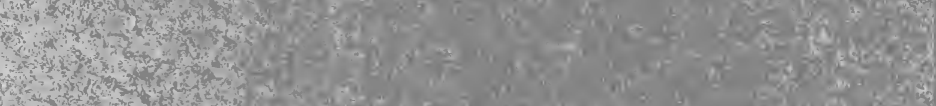

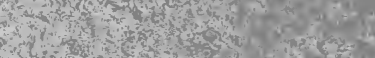

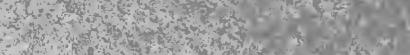

1.

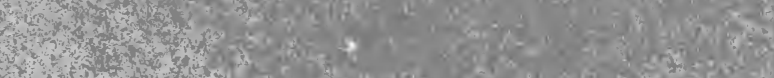

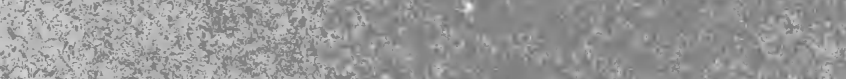
3
4

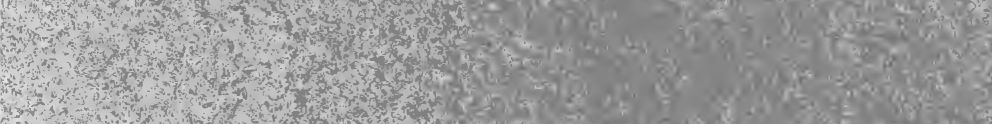

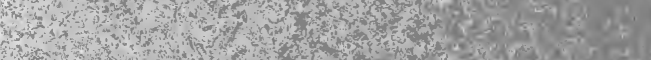

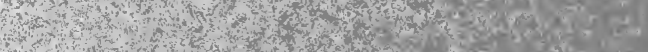

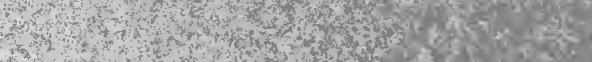

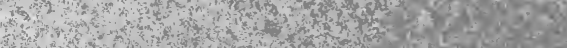

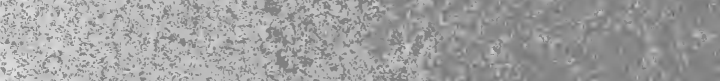
Str.

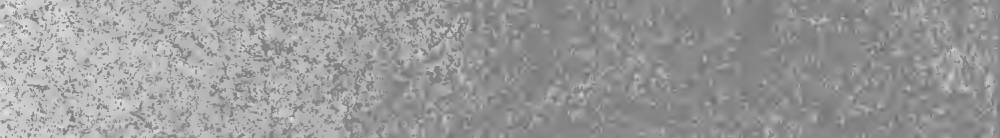
2.

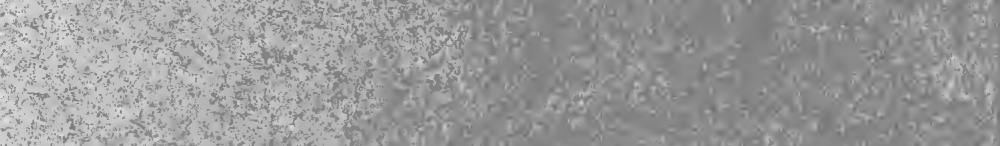
(1) 



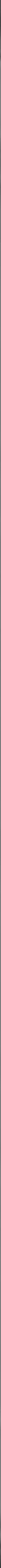





\section{SHAKESPEARE ILLOSTRATED}


Huic versatile ingenium sic pariter ad omnia fuit, ut natum ad id unum diceres, quodcumque ageret.-Livy, xxxix. 40. 


\section{SHAKESPEARE}

\section{ILLUSTRATED BY THE LEX SCRIPTA}

BY

\section{WILLIAM LOWES RUSHTON}

OF GRAY'S INN, BARRISTER-AT-LAW

Corresponding Member of the Berlin Society for the Study of Modern Languages : A uthor of 'Shakespeare a Lawyer,' 'Shakespeare's Legal Maxims,'

'Shakespeare Illustrated by Old Authors,' 'Shakespeare's Testamentary Language,' \&c.

And every statute coude he plaine by rote-Chaucer

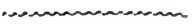

\section{THE FIRST PART}

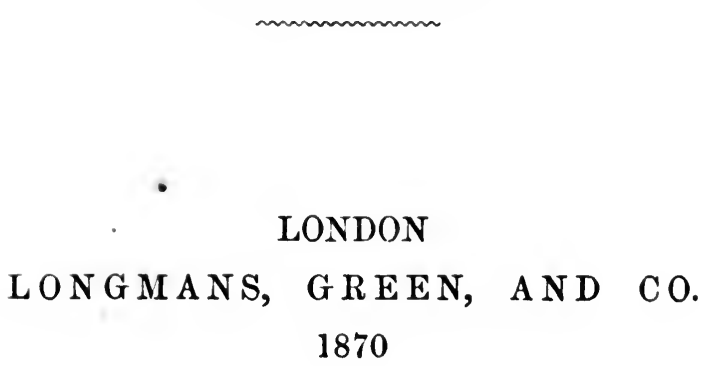



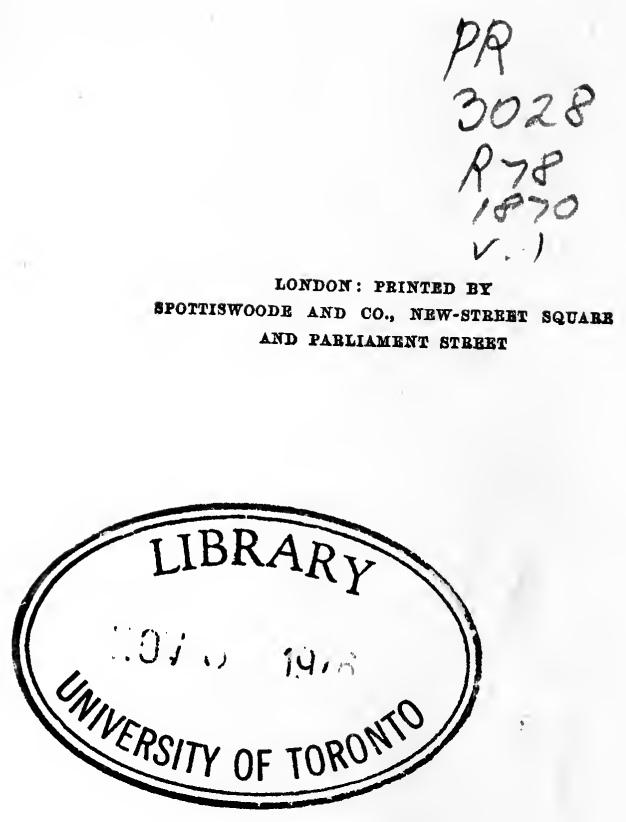


\section{NOT I C E.}

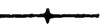

MANY of these illustrations were contributed to the Berlin Society for the Study of Modern Languages, and afterwards published in the 'Archiv fuir das Studium der neueren Sprachen und Literaturen.'

5 Essex Court, 'Temple :

Michaelmas Term, 1869. 



\section{SHAKESPEARE ILLUSTRATED}

BY THE

\section{LEX SCRIPTA.}

I THink I shall be able to illustrate and explain many obscure passages and words and expressions of doubtful meaning in the works of Shakespeare by extracts from ancient English statutes.

Suf. Lord cardinal, the king's further pleasure is, Because all those things you have done of late, By your power legatine, within this kingdom, Fall into the compass of a premunire, That therefore such a writ be sued against you; To forfeit all your goods, lands, tenements, Chattels, and whatsoever, and to be Out of the king's protection. This is my charge. Henry VIII., Act iii. Sc. 2.

In this passage Shakespeare uses the exact letter of the statute law. 
A Præmunire (so called from the words of the writ Promunire facias, or Promonerifacias, signifying the writ and the offence on which the writ is grounded), is an offence whereby we shall incur the same punishment which is inflicted upon those who transgress the 16 Richard II., cap. 5, which ordained and established:-

Qe si ascun purchace ou pursue, ou face purchacer ou pursuer en la courte de Rome ou aillours ascuns tieux translations, processes \& sentences de escomengementz, bulles, instrumentz, ou autre chose queconqe qe touche le Roi nostre Seignur encountre luy, sa corone \& regalie ou son Roialme come devant est dit, \& ceux qe les porte deinz le Roialme ou les receive ou facent notification ou autre execution queconqe deinz mesme le Roialme ou dehors, soient ils lour notairs, procuratours, meintenours, abbettours, fautours et conseillours mys hors de la protection nostre dit Seignur le Roy et lours terres et tenementz, biens et chatieux forfaitz au Roi nostre Seignur, et qils soient attachez par lour corps fils purront estre trovez et amesnex devaunt le Roy et son conseil pur y respondre es cases avaunditz ou qe processe soit fait devers eux par premunire facias en manere come est ordeigne en autres estatutz des provisours et autres qui seuent en autry courte en derogation de la nostre Seignur le Roy.16 Richard II., cap. v. 
That if any purchase or pursue, cause to be purchased or pursued, in the Court of Rome, or elsewhere, by any such translations, processes, and sentences of excommunications, bulls, instruments, or any other things whatsoever which touch the King against him, his crown, and his regality, or his realm, as is aforesaid, and they which bring within the realm, or them receive, or make thereof notification, or any other execution whatsoever within the same realm or without, that they, their notaries, procurators, maintainers, abettors, fautors, and counsellors, shall be put out of the King's protection, and their lands and tenements, goods and chattels, forfeit to our Lord the King; and that they be attached by their bodies, if they may be found, and brought before the King and his Council, there to answer the cases aforesaid, or that process be made against them by promunire facias, in manner as it is ordained in other statutes of provisors, and other which do sue in any other court in derogation of the regality of our Lord the King.

Boling. My gracious lord, I come but for mine own.

K. Rich. Your own is yours, and I am yours, and all.

Boling. So far be mine, my most redoubted lord, As my true service shall deserve your love.

Richard II., Act iii. Sc. 3.

Bolingbroke calls King Richard II. not only 
gracious lord but also redoubted lord, and in the preamble of this statute (Richard II.) Richard is styled ' redoubted lord.'

Item, come les communes du Roialme en cest present parlement eient monstrez a nostre tresredoute Seignur le Roi grevousement compleignantz, \&c.

Item, whereas the Commons of the realm in this present Parliament have showed to our redoubted Lord the King, grievously complaining, \&c.

Host. My hand, bully; thou shalt have egress and regress;-said I well? and thy name shall be Brook. It is a merry knight. Will you go, anheires?

Merry Wives of Windsor, Act ii. Sc. 1.

Gadshill. I am joined with no foot-land rakers, no long staff sixpenny strikers, none of these mad mustachio, purple-hued malt-worms; but with nobility and tranquillity, burgomasters and great oneyers, such as can hold in, such as will strike sooner than speak, and speak sooner than drink, and drink sooner than pray.

$$
1 \text { Henry IV., Act ii. Sc. } 1 .
$$

' An-heires,' 'oneyers.' I think these words are misprints of 'one ears.' Cutting off the ear was a punishment inflicted long before, during, and after Shakespeare's time for various offences. The following are some of the 
conjectures which have been made by various commentators :-

An-heires.-Mynheers; on, here; on heris; on hearts; on, heroes; and hear us; cavaleires; eh, sir?

Oneyers. - One-eyers ; oneraries ; moneyers ; seignors; owners; one-eers; myn-heers; onyers; ones, yes; wan-dyers.

Marc. Fie, brother, fie! teach her not thus to lay

Such violent hands upon her tender life.

Tit. How now! has sorrow made thee dote already?

Why, Marcus, no man should be mad but I. What violent hands can she lay on her life?

Titus Andronicus, Act ii. Sc. 3.

Malcolm. My thanes and kinsmen, Henceforth be earls, the first that ever Scotland In such an honour named. What's more to do, Which would be planted newly with the time, As calling home our exiled friends abroad That fled the snares of watchful tyranny; Producing forth the cruel ministers Of this dead butcher and his fiend-like queen, Who, as 'tis thought, by self and violent hands Took off her life.

Macbeth, Act v. Sc. 7.

Forasmuch as of late divers and many outragious and barbarous behaviours and acts have been used 
and committed by divers ungodly and irreligious persons, by quarrelling, fraying and fighting openly in churches and churchyards: Therefore it is enacted that if any person whatsoever shall, at any time after the first day of May next coming, by words only, quarrel, chide or brawl in any church or churchyard, that then it shall be lawful unto the Ordinary of the place where the same offence shall be done and proved by two lawful witnesses, to suspend every person so offending; that is to say, if he be a layman, $a b$ ingressu ecclesia, if he be a clerk, from the ministration of his office, for so long a time as the said Ordinary shall by his discretion think meet and convenient, according to the fault.

II. And further it is enacted by the authority aforesaid, that if any person or persons, after the said first day of May, shall smite or lay violent hands upon any other, either in any church or churchyard, that then, ipso facto, every person so offending shall be deemed excommunicate, and be excluded from the fellowship and company of Christ's congregation.

III. And also it is enacted that if any person, after the said first day of May shall maliciously strike any person with any weapon in any church or churchyard, or after the same first day of May shall draw any weapon in any church or churchyard, to the intent to strike another with the same weapon, that then every person so offending, and thereof being convicted by verdict of xii. men, or by his own confession, or by two lawful witnesses, 
before the justices of assize, justices of oyer and determiner, or justices of peace in their sessions, by force of this Act, shall be adjudged by the same justices before whom such person shall be convicted, to have one of his ears cut off; and if the person or persons so offending have none ears, whereby they should receive such punishment as is before declared, that then he or they to be marked and burned in the cheek with an hot iron, having the letter $\mathrm{F}$ therein, whereby he or they may be known and taken for fray-makers and fighters; and besides that, every such person to be and stand ipso facto excommunicated, as is aforesaid. $-5 \& 6$ Edward VI., cap. iv.

Cutting off one ear was a punishment inflicted upon those who malicious struck any person in any churchyard; and Gadshill says he is joined with no sixpenny strikers, \&c. but great oneyers such as can hold in, such as will strike sooner than speak, \&c. and it may be considered worthy of consideration whether Shakespeare does not mean by one ears persons upon whom this punishment, for striking, had been inflicted, and who had consequently only one ear.

The statute itself testifies to the frequency of this punishment in former times, for it enacts what punishment should be inflicted 
upon those who have none ears; in other words, what punishment those persons should receive who, having offended twice before and lost one ear each time they were punished, had none ears. One ears and oneyers have each seven letters, and none ears and an-heires have each eight letters.

A confirmation of the stat. of 3 Edward I., cap. 34, and 2 Richard II., stat. 1, cap. 5, touching telling of news. Justices of peace in every shire, city, \&c., shall have authority to hear and determine the said offences, and to put the said two statutes in execution. If any person shall be convicted or attainted for speaking maliciously of his own imagination any false, seditious, and slanderous news, saying, or tales, of the King or Queen, then he shall for his first offence be set on the pillory in some market-place near where the words were spoken, and have both his ears cut off, unless he pay to the Queen an hundred pound within one month after judgment given, and also shall be three months imprisoned; and if he shall speak any such slanderous and seditious news or tales of the speaking or report of any other, then he shall be set on the pillory and have one of his ears cut off, unless he pay an hundred marks to the Queen's use within one month after, and shall be one month imprisoned : and if he shall do it by book, rhime, ballad, letter, or writing, he shall have his right hand stricken off : and if any 
person, being once convicted of any of the offences aforesaid, do afterward offend, he shall be imprisoned during his life, and forfeit all his goods and chattels. $-1 \S 2$ Philip and Mary, cap. 3.

Where divers and sundry malicious and envious persons, being men of evil and perverse dispositions, and seduced by the instigation of the devil, and minding the hurt, undoing, and impoverishment of divers of the King's true and faithful subjects, as enemies to the commonwealth of this realm, and as no true or obedient subjects unto the King's Majesty, of their malicious and wicked minds, have of late invented and practised a new damnable kind of vice, displeasure, and damnifying of the King's true subjects and the commonwealth of this realm, as in secret burning of frames of timber prepared and made by the owners thereof, ready to be set up and edified for houses, cutting out of heads and dams of pools, motes, stews, and several waters; cutting off conduit heads or conduit pipes; burning of wains or carts loaden with coals or other goods; burning of heaps of wood, cut, felled, and prepared for making of coals; cutting out of beasts' tongues; cutting off the ears of the King's suljects ; barking of apple-trees, pear-trees, and other fruit trees; and divers other like kinds of miserable offences, to the great displeasure of Almighty God and of the King's Majesty, and to the most evil and pernicious example that hath been seen in this realm.

The fourth section of this statute enacts, amongst other things:- 
That if any person or persons maliciously, willingly, or unlawfully cut or cause to be cut off the ear or ears of any of the King's subjects, otherwise than by authority of law, chance-medley, sudden affray, or adventure; or maliciously, willingly, or unlawfully bark any apple-trees, pear-trees, or other fruit-trees of any other person or persons; that then every such offender and offenders shall not only lose and forfeit unto the party grieved treble damages for such offence or offences, the same to be recovered by action or trespass to be taken at the common law, but also shall lose and forfeit to the King's Majesty and his heirs, for every such offence, $x l$. sterling in name of a fine.-37 Henry VIII., cap. vii.

The malicious and envious persons described in this statute not only inflicted pain upon the King's subjects by cutting their ears off, but they also gave them an infamous appearance, for a person with one ear or ' non-ears' looked like a transgressor of the criminal law.

The 5th Elizabeth, cap. xiv., an Act against forgers of false deeds and writings, enacts that any person forging a false deed should have both his ears cut off.

Est enim furtum de re magna et parva, pro minimo tamen latrocinio 12 denariorum et infra, nullus morti condemnetur; pro hujusmodi modicis delictis inventa fuerunt judicialia pilloria, et deformitates 
corporum, ut scissio auricularum.--Fleta, lib. I., cap. 38 , scc. 10.

Des cinsors des burses, voylons que celuy que la burse coupa si auter maviese ne eyt feyt, eyt judgment de Pillory; \& silz eyent emble auter chose meinder de 12. deniers, perdent un oraile, \& si le chose passe 12. deniers eyent judgment de mort.Britton, fo. 24 b.

Bagot. My Lord Aumerle, I know your daring tongue

Scorns to unsay what once it hath deliver'd. In that dead time when once Gloucester's death was plotted,

I heard you say, 'Is not my arm of length, That reacheth from the restful English court As far as Calais, to mine uncle's head?'

Richard II., Act iv. Sc. 1.

K. Hen. If, Duke of Burgundy, you would the peace,

Whose want gives growth to the imperfections Which you have cited, you must buy that peace With full accord to all our just demands :

Whose tenours and particular effects

You have enscheduled briefly in your hands.

Henry $V$., Act v. Sc. 2.

Item, the King our Sovereign Lord considereth, That by the negligence, misdemeaning, favour, and other inordinate causes of justices of peace in every shire of this his realm, the laws and ordinances made 
for the politique weal, peace, and good rule of the same, and for the perfect surety, and restful living of his subjects of the same, be not duly executed according to the tenour and effect that they were made and ordained for; wherefore his subjects being grievously hurt, and out of surety of their bodies and goods, to his great displeasure, for to him is nothing more joyous than to know his subjects to live peaceably under his laws and to increase in wealth and prosperity, and to avoid such enormities and injuries, so that his said subjects may live restfully under his peace and laws, to their increase. He will that it be ordained and enacted by authority of this said Parliament, that every justice of peace within every shire of this realm, within the shire where he is justice of peacc, do cause openly and solemnly to be proclaimed yearly four times a year, in four principal sessions, the tenor of this proclamation to this bill annexed; and that every justice of peace being present at any of the said sessions, if they cause not the said proclamation for to be made in form abovesaid, shall forfeit unto our Sovereign Lord at that time xxs.-4 Henry VII., cap. 12.

'Restful,' full of rest, easily.

Mess. My lord, a prize, a prize! here's the Lord Say, which sold the towns in France; he that made us pay one and twenty fifteens, and one shilling to the pound, the last subsidy.

2 Henry VI., Act iv. Sc. 7.

York. I never read but England's kings have had 
Large sums of gold and dowries with their wives; And our King Henry gives away his own, To match with her that brings no vantages.

Glou. A proper jest, and never heard before, That Suffolk should demand a whole fifteenth For costs and charges in transporting her!

2 Henry VI., Act i. Sc. 1.

Pro hac autem donatione et concessione libertatum istarum, et aliarum libertatum contentarum in charta nostra de libertatibus forestæ, archiepiscopi, abbates priores, comites, barones, milites, liberi tenentes, et omnes de regno nostro dederunt nobis quintodecimam partem omnium mobilium suorum.-Magna Charta, 9 Henry III.

\section{Hot.}

Then to the point.

In short time after, he deposed the king; Soon after that, deprived him of his life ; And in the neck of that, task'd the whole estate. 1 Henry $I V$., Act iv. Sc. 3.

Coke, in his exposition of this chapter, says :-

For this gift and graunt by the King, of the liberties contained in this great charter, and of others contained in the King's charter of liberties of the forest, the archbishops, bishops, abbots, priors, earles, barons, knights, free-holders, and other the King's subjects, citizens and burgesses (assembled in Parliament) gave unto the King one fifteenth; which proveth, that as the fifteenth was graunted by Par- 
liament, so was this great charter also graunted by authority of the same; but since this time the manner of the fifteenth is altered; for now the fifteenth, which is also called the Task, is not originally set upon the polles, as at this time it was, but now the fifteenth is certainly rated upon every towne.2 Inst. 77.

K. Hen. I have not been desirous of their wealth,

Nor much oppress'd them with great subsidies, Nor forward of revenge, though they much err'd. 3 Henry VI., Act iv. Sc. 8.

Nor. Arm, arm, my lord; the foe vaunts in the field.

K. Rich. Come, bustle, bustle; caparison my horse.

Call up Lord Stanley, bid him bring his power: I will lead forth my soldiers to the plain, And thus my battle shall be ordered:

My foreward shall be drawn out all in length, Consisting equally of horse and foot;

Our archers shall be placed in the midst: John Duke of Norfolk, Thomas Earl of Surrey, Shall have the leading of this foot and horse. They thus directed, we will follow In the main battle, whose puissance on either side Shall be well winged with our chiefest horse. Richard III., Act v. Sc. 3.

Subsidie (says Coke) is derived of the verb susidiari, which signifieth to be ready to help at need, 
unde subsidium, which signifieth aide and help at need, so properly called, when souldiers were ready to help the foreward of the battel: and aptly was the word so derived, as well because that which we call now subsidia, subsidies, were anciently called auxilia, aides, granted by Act of Parliament upon need and necessity : as also, for that originally and principally they were granted for the defence of the realm, and the safe keeping of the seas, \&c. Communia pericula requirunt communia auxilia. This word subsidia is common, as well to the English as to the French. Concerning subsidies, hear what a stranger truly writeth. Reges Anglia nihil tale, nisi convocatis prius ordinibus, et assentiente populo, suscipiunt. Quæ consuetudo valde mihi laudanda videtur; interveniente enim populi voluntate et assensu, crescit robur et potentia regum, et major est ipsorum authoritas, et feliciores progressus. Subsidies taken in their generall sense for parliamentary aides are divided into perpetuall and temporary: perpetuall into three parts, viz. into custuma antiqua, sive magna, custuma nova sive parva, and into custome of broad cloth. Temporary, whereof there are three kindes, viz.: 1. Of tonnage and poundage of ancient time granted for a year or yeares incertainly, and of latter times for life. 2. A subsidie after the rate of $4 s$. in the pound for lauds, and $2 s .8 d$. for goods, and $3 s$. for an aide called a fifteenth.4 Inst. 29.

The word foreward is evidently used by 
King Richard to signify the van-guard of his army, and in that sense it is used by Coke.

K. Hen. I have not been desirous of their wealth,

Nor much oppress'd them with great subsidies, Nor forward of revenge, though they much err'd. 3 Henry VI., Act iv. Sc. 8.

And although the adjective forward used in this passage by Henry VI. is spelt without the ' $e$,' it may perhaps be worthy of notice that it here follows the word subsidy, which Coke says ' signifieth aid and help at need, so properly called, when soldiers were ready to help the foreward of the battle.'

Scar. The greater cantle of the world is lost With very ignorance; we have kissed away Kingdoms and provinces.

Antony and Cleopatra, Act iii. Sc. 8.

Hot. Methinks my moiety, north from Burton here,

In quantity equals not one of yours:

See how this river comes me cranking in, And cuts me from the best of all my land A huge half-moon, a monstrous cantle out.

1 Henry IV., Act iii. Sc. 1.

First Car. What, ostler! come away and be hanged! come away. 
Sec. Car. I have a gammon of bacon and two razes of ginger, to be delivered as far as Charingcross.-1 Henry IV., Act ii. Sc. 1.

Tolnetum ad molendinum secundum communem consuetudinem regni et secundum fortitudinem cursus aque capiatur vel ad vicesimum granum vel ad vicesimum quarterium grani. Et mensura per quam tolnetum debet capi sit concordans mensure Domini Regis et capiatur tolnetum per rasum et nichil cum cumulo seu cantello. Et si furnarii inveniunt molendinariis necessaria sua nichil capiatur preter debitum tolnetum. Et si aliter fecerint graviter puniatur.-Temporibus Henrici III., Edwardique I. et II.

The toll of a mill shall be taken according to the custom of the land, and according to the strength of the watercourse, either to the twentieth or four-andtwentieth corn. And the measure whereby the toll must be taken shall be agreeable to the King's measure, and toll shall be taken by the rase, and not by the heap or cantel. And in case that the farmers find the millers their necessaries, they shall take nothing besides their due toll; and if they do otherwise they shall be grievously punished.

Standardum busselli galonis et ulne et signa quibus mensure sunt signande sint sub custodia majoris et ballivorum et sex legalium de villa juratorum coram quibus omnes mensure signentur. Nullum genus bladi vendatur per cumulum seu can- 
tellum preter avenam, braseum seu farinam.-Temporibus Henrici III., Edwardique I. et II. cap. ix.

The standard bushels and ells shall be in the custody of the mayor and bailiffs, and of six lawful persons of the same town being sworn, before whom all measures shall be sealed. No manner of grain shall be sold by the heap or cantel, except it be oats, malt and meal.

Cowell says cantel seems to signify the same with what we now call lump, as to buy by measure or by the lump. It signifies also a piece of anything, as a cantel of bread, cheese, and the like (Interpr.).

Rase raseria seems to have been a measure of corn now disused. Debentur ei annuatim decem et octo raserice avenæ, et sex raseriæ hordei, \&c. (Cowell, Spelman.) Rasus alleorum, a rase of onions, thus computed in Fleta, lib. 2, cap. 12, s. 12: 'Rasus alleorum continet $\mathrm{xx}$. flones, et qualibet flones xxv. capita.'

Lear. Of all these bounds even from this line to this,

With shadowy forests and with champains rich'd, With plenteous rivers and wide-skirted meads, We make thee lady: to thine and Albany's issue Be this perpetual. Act 1. Sc. 1.

To the King our Sovereign Lord, praieth unto your Highness your true subjects and Commons in this present Parliament assembled, That where in 
time passed this your realm of England hath greatly been encreased and riched by the mean of true making and draping, and also of true dying of woollen cloth, whereby a great substance of the people of your said realm have been set on work and not fallen to idlenesse, as dailly nowe they doo, but thereby truly gotten ther levying.-1 Richard III., cap. viii.

King. Go, call before me all the lords in court. Sit, my preserver, by thy patient's side; And with this healthful hand, whose banish'd sense Thou hast repeal'd, a second time receive The confirmation of my promised gift, Which but attends thy naming.

Enter three or four Lords.

Fair maid, send forth thine eye : this youthful parcel Of noble bachelors stand at my bestowing,

O'er whom both sovereign power and father's voice I have to use: thy frank election make; Thou hast power to choose, and they none to forsake. All's Well that Ends Well, Act ii. Sc. 3.

Et pur ceo que elections doient estre frankes, cy defend le roy sur la greeve forfeiture, que nul haute home, ne auter, per poyar des armes, ne per malice ou menaces, ne disturbe de faire franke election.3 Edward I. (Westminster the First), cap. v.

And because elections ought to be free, the King commandeth upon great forfeiture that no man by force of arms, nor by malice, or menacing, shall disturb any to make free election.-2 Inst. 168. 
The reader will perceive that the King says to Helena, 'Thy frank election make', and according to this chapter of Westminster the First,_elections doient estre frankes,' also ' nul haute home, \&c., ne disturbe de faire franke election,'-and the King uses the verb 'make,' which is the English of ' faire.'

First Lord. Wrong not yourself, then, noble Helicane;

But if the prince do live, let us salute him, Or know what ground 's made happy by his breath. If in the world he live, we'll seek him out; If in his grave he rest, we'll find him there; And be resolved he lives to govern us, Or dead, give's cause to mourn his funeral, And leave us to our free election.

Pericles, Act ii. Sc. 4.

'There were,' says Coke, 'two mischiefs before the making of this statute: 1. For that elections were not duly made; 2 . That elections were not freely made; and both these ayainst the ancient maxim of the law, Fiant electiones rite et libere sine interruptione aliqua; and again, Electio libera est; for before this Act in the regular reign of Henry III. the electors had neither their free, nor their due elections, for sometimes by force, sometimes by menaces, and sometimes by malice, the electors were framed, and wrought to make election of men unworthy, or not eligible, so far as their election was neither due nor free: this Act rehearseth the old 
rule of the common law (for that elections ought to be free), wherein both the said points are included : 1 st, it must be a due election; and 2 nd, it must be a free election.-2 Inst. 169.

Doll. For God's sake thrust him down stairs: I cannot endure such a fustian rascal.

2 Henry IV., Act iv. Sc. 4.

Curt. Come, you are so full of cony-catching!

Gru. Why, therefore fire; for I have caught extreme cold. Where's the cook? is supper ready, the house trimmed, rushes strewed, cobwebs swept; the serving-men in their new fustian, their white stockings, and every officer his wedding garment on? Be the jacks fair within, the jills fair without, the carpets laid, and every thing in order?

Taming of the Shrew, Act iv. Sc. 1.

Prayen the commons in this present Parliament assembled, that whereas fustians brought from the parts beyond the sea unshorn into this realm, have been and should be most profitable cloth for doublets and for other wearing clothes, greatly used among the common people of this realm, and longest have endured of anything that have come into the same realm from the said parts to that intent, for that the cause hath been that such fustians afore this time have been truly wrought and shorn with the broad shear, and with no other instruments or other deceitful mean occupied upon the same; now so it is, that divers persons by subtil and undue sleights and means, have deceivably imagined and contrived instruments of iron, with which irons, in the most 
highest and secret places of their houses, they strike and draw the said iron of the said fustians unshorn; by means whereof they pluck off both the nap and cotton of the same fustians, and break commonly both the ground and threads in sunder, and after by crafty sleeking they make the same fustians to appear to the common people fine, whole, and sound; and also they raise up the cotton of such fustians, and then take a light candle and set it in the fustian burning, which sindgeth and burneth away the cotton of the same fustian from the one end to the other, down to the hard threads, instead of shearing, and after that put them in colour, and so subtilly dress them, that their false work cannot be espied, without it be by workmen shearers of such fustians or by the wearers of the same; and so by such subtilities, whereas fustians made in doublets, or put to any other use, were wont and might endure the space of two years and more, will not endure now whole by the space of four months scarcely, to the great hurt of the poor commons and servingmen of this realm, to the great damage, loss, and deceit of the king's true subjects, buyers and wearers of such fustian. For remedy whereof, be it enacted, ordained, and established, that no such iron or instruments, nor any other untrue, subtil, mean, or sleight be from henceforth used upon any fustian within this realm, but only by the broad shears, upon forfeiture of xxs. to be levied for every default of every such person or persons hereafter offending and using any such deceivably instruments or sleights, 
as is aforesaid ; the one half of the forfeitures to be to the King our Sovereign Lord, and the other half to him or them that will sue for the same forfeitures by action of debt, bill, plaint, or information in any of the King's Courts of Record, where the same may be determined after the course of the common law, and that the defendant in such behalf in no wise be admitted to urge his law, nor that any protection or essoin be in the same allowable. And over this, be it ordained by the said authority, that the mayor and wardens of shearmen of the city of London for the time being have authority to enter and search the workmanship of all manner persons occupying the broad shear, as well fustians as cloth; and the execution of this present Act to be as well of denizens as of foreigners and strangers.-11 Henry VII., cap. xxvii.

The preamble of 39th Elizabeth, cap. xiii., which was passed when Shakespeare was about thirty-three years old, recites, that amongst her Majesty's people the wearing of fustians had lately grown to more use than ever it was before :-

Whereas by an Act made in the eleventh year of King Henry the Seventh, the mayor and wardens of shearmen of the city of London for the time being, should have authority to enter and search the workmanship of all manner of persons occupying the broad shear, as well fustians as cloth 
and the execution of the said Act for using any instruments of iron, or other untrue subtil mean or slight in dressing the same: Since which time, for that the Lord Mayor of London cannot conveniently go in his own person to make the said search, by reason of his other weighty occasions, divers have resisted the wardens of the shear-men going abroad in offering to make search according to the said law; and for want of due and daily search in that behalf, divers have of late days put in use the iron instruments, and other sleights forbidden by the recited Act, to the great deceit of her Majesty's people, amongst whom the wearing of fustians is lately grown to more use, as may seem, than ever it was before time.-39 Elizabeth, cap. xiii.

Fal. Keep them off, Bardolph.

Fang. A rescue! a rescue!

Host. Good people, bring a rescue or two. Thou wo't, wo't thou? thou wo't, wo't ta? do, do, thou rogue! do, thou hemp-seed!

Fal. Away, you scullion! you rampallian! you fustilarian! I'll tickle your catastrophe.

$$
2 \text { Henry IV., Act ii. Sc. } 1 .
$$

The reader may be of opinion, after reading these statutes, that the word 'fustilarian' in this passage means one who wears fustian, cr, in other words, to use the language of the preamble of the 11 Henry VII., cap. xxviii., one of the common people or serving men. 


\section{Mal. [reads]}

I may command where I adore;

But silence, like a Lucrece knife,

With bloodless stroke my heart doth gore:

M, O, A, I, doth sway my life.

Fab. A fustian riddle!

Twelfth Night, Act ii. Sc. 5 .

Cas. I will rather sue to be despised than to deceive so good a commander with so slight, so drunken, and so indiscreet an officer. Drunk? and speak parrot? and squabble? swagger? swear? and discourse fustian with one's own shadow? thou invisible spirit of wine, if thou hast no name to be known by, let us call thee devil!

Othello, Act ii. Sc. 3.

The word fustian, as it is here used by Fabian and Cassio, seems to signify something common or of inferior quality.

Ther. E'en so; a great deal of your wit, too, lies in your sinews, or else there be liars. Hector shall have a great catch, if he knock out either of your brains : a' were as good crack a fusty nut with no kernel.

\section{Troilus and Cressida, Act ii. Sc. 2.}

Hamlet. Sure, he that made us with such large discourse,

Looking before and after, gave us not That capability and god-like reason

To fust in us unused.

Act iv. Sc. 4. 
And although the adjective 'fusty,' used by Thersites, evidenly signifies ' mouldy,' and the verb 'fust,' used by Hamlet, signifies also ' to get mouldy from want of use :'

Ulysses. Sometime, great Agamemnon, Thy topless deputation he puts on, And, like a strutting player, whose conceit Lies in his hamstring, and doth think it rich To hear the wooden dialogue and sound 'Twixt his stretch'd footing and the scaffoldage,Such to-ke-pitied and o'er-wrested seeming He acts thy greatness in: and when he speaks, 'Tis like a chime a-mending; with terms unsquared, Which, from the tongue of roaring Typhon dropp'd, Would seem hyperboles. At this fusty stuff The large Achilles, on his press'd bed lolling, From his deep chest laughs out a loud applause. Troilus and Cressida, Act i. Sc. 3.

Yet it may be considered probably that Ulysses uses the adjective 'fusty' as descriptive of the wretched imitation; or, to use the words of Cassio, the 'fustian discourse' of Patroclus.

Host. Come, I'll drink no proofs nor no bullets: I'll drink no more than will do me good, for no man's pleasure, I.

Pist. Then to you, Mistress Dorothy; I will charge you. 
LACK LINEN. MOULDY ROGUE. FUSTY PLEBEIAN. 27

Dol. Charge me! I scorn you, scurvy companion. What! you poor, base, rascally, cheating, lack-linen mate! Away, you mouldy rogue, away! I am meat for your master.

2 Henry IV., Act ii. Sc. 4.

The adjective 'mouldy' in this passage may be used in a double sense. Doll calls Pistol 'a poor, base, rascally, cheating, lack-linen mate,' and also a 'mouldy rogue.' Those who were poor lacked linen, and wore fustian, a material of inferior quality, much worn by the common people and serving men: the words mouldy and fusty are synonymous terms: a mouldy rogue may, therefore, suggest the idea of a fusty rogue, or one who wore fustian; and Cominius, in 'Coriolanus,' speaks of ' fusty plebeians':-

Com. If I should tell thee o'er this thy day's work,

Thou'ldst not believe thy deeds : but I'll report it Where senators shall mingle tears with smiles, Where great patricians shall attend and shrug, I' the end admire, where ladies shall be frighted, And, gladly quaked, hear more; where the dull tribunes,

That, with the fusty plebeians, hate thine honours, 
Shall say against their hearts 'We thank the gods Our Rome hath such a soldier.'

Yet camest thou to a morsel of this feast, Having fully dined before.

Act i. Sc. 9.

Besides, Doll says afterwards, in the same scene, referring to Pistol, 'I cannot endure such a fustian rascal.'

Sebas.

There's something in't

That's deceivable.

\section{Twelfth Night, Act iv. Sc. 3.}

Boling. I shall not need transport my words by you ;

Here comes his grace in person.

My noble uncle! [Kneels.

York. Show me thy humble heart, and not thy knee,

Whose duty is deceivable and false.

Richard II., Act ii. Sc. 3.

The Queen's most excellent Majesty, with the advice of her Highness' Lords spiritual and temporal, and the Commons in this present Parliament assembled, weighing and considering the good and godly purposes of divers and sundry statutes heretofore made and ordained for the true making and working of woollen cloth, to be frustrated and deluded by straining, stretching, want of weight, 
flocks, sollace, chalk, flour, deceitful things, subtil sleights, and untruths, so as the same clothes be put in water are found to shrink, be rewey, pursey, squally, cockling, bandy, light, and notably faulty, to the great dislike of foreign princes, and to the hindrance and loss of the buyer and wearer: for redress thereof, is pleased and willeth it to be enacted, and by the authority of this present Parliament it is enacted, that from and after the Feast of the Purification of the Blessed Virgin Mary next ensuing, no person or persons shall put any hair, flocks, thrums, or yarn made of lamb's wool, or other deceivable thing or things, into or upon any broad woollen cloth, half-cloth, kersie, dozen penistone or cotton, Taunton cloth, Bridgwater, Dunster cotton, upon pain to forfeit every such cloth, half-cloth, kersie, frize, dozen penistone and cotton, and other woollen cloth, of what nature, kind, or name soever, whereunto or whereupon any such hair be so put, any law, statute, dispensation, allegation, or toleration, to the contrary thereof in any wise notwithstanding, and upon pain that every person and persons which shall buy, gather, or procure any hair, flocks, thrums, yarn of lamb's wool, or other deceivable thing or things whatsoever, for that intent and purpose, to forfeit the same hair, flocks, thrums, yarn of lamb's wool, and other deceivable thing and things whatsoever.-43 Elizabeth, cap. x.

In the ancient statutes the words 'deceivable' and 'deceitful' are synonymes: for 
example, the 43rd Elizabeth, cap. x., speaks first of deceitful things as subtil sleights and untruths; and afterwards, referring to the same 'subtel sleights and untruths,' speaks of them as deceivable things.

Ros. My lord, you once did love me.

Ham. So I do still, by these pickers and stealers.

Hamlet, Act iii. Sc. 2.

D. Pedro. What, a feast, a feast?

Claud. I' faith, I thank him; he hath bid me to a calf's head and a capon; the which if $I$ do not carve most curiously, say my knife's naught. Shall I not find a woodcock too?

Much Ado about Nothing, Act v. Sc. 1.

Canterbury. Hugh Capet also, who usurped the crown

Of Charles the duke of Lorraine, sole heir male Of the true line and stock of Charles the Great, To find his title with some shows of truth, Though, in pure truth, it was corrupt and naught, Convey'd himself as heir to the Lady Lingare. Henry V. Act ii. Sc. 3.

To the King and Sovereign Lord, and to the noble lords spiritual and temporal and commons in this present Parliament assembled, humbly and lamentably shewn and complain unto your most abundant grace, your humble subjects the pewterers 
and brasiers of your cities of London and York, and of all other places of this your realm, That whereas many simple and evil-disposed persons of this your realm of England, using the said crafts, daily go about this your realm, from village, from town, and from house to house, as well in woods and forests and in other places, to buy pewter and brass; and that knowing thieves and other pickers that steal as well pewter and brass belonging to your Highness and under your mark, and to the lords spiritual and temporal, as to other your subjects of this your realm, bring such stolen vessels unto them in such hid places, or into corners of cities and towns, and there sell much part of it to strangers, which carry it over the sea by stealth. And also the said persons so going about, and divers other using the said crafts, use to make new vessels, and mix good metal and bad together, and make it naught, and sell them for good stuff, where indeed the stuff and metal thereof is not worth the fourth that it is sold for, to the great hurt, deceit, and loss of your subjects. Also divers persons using the said crafts, have deceivable and untrue beams and scales, that one of them would stand even with twelve pound weight at one end against a quarter of a pound at the other end, to the singular advantage of themselves, and to the great deceit and loss of your subjects, buyers and sellers with them. For reformation of the premises, it would please your Highness, of your most abundant grace, with the advice of the lords spiritual and temporal, and the commons in this pre- 
sent Parliament assembled, and by authority of the same, to enact and establish that no person or persons using the said crafts of pewterers and brasiers, from henceforth shall sell or change any pewter or brass, new or old, at any place or places within your realm, but only in open fairs or markets, or in their own dwelling-houses, but if they be desired by the said buyers of such ware, upon pain of forfeiture to our Sovereign Lord the King for every such default.-X. li. 19 Henry VII. cap. vi.

\section{Nurse.} There's no trust,

No faith, no honesty in men; all perjured, All forsworn, all naught, all dissemblers.

Romeo and Juliet, Act iii. Sc. 2.

Oph. Will he tell us what this show meant?

Ham. Ay, or any show that you'll show him: be not you ashamed to show, he'll not shame to tell you what it means.

Oph. You are naught, you are naught: I'll mark the play.

\section{Hamlet, Act iii. Sc. 2.}

Cym.

My tears that fall,

Prove holy water on thee! Imogen,

Thy mother's dead.

Imo. I'm sorry for't, my lord.

Cym. O, she was naught; and long of her it was That we meet here so strangely : but her son Is gone, we know not how nor where. Cymbeline, Act v. Sc. 5 , 
The word naught, in the 19th Henry VII., cap. 6 , evidently means 'bad,' or worthless, if we consider the context in the preamble, which recites ' that persons used to make new vessels, and mix good metal and bad together, and make it naught, and sell them for good stuff, where indeed the stuff and metal thereof is not worth the fourth part,'-and in this sense it is sometimes used by Shakespeare, as it seems to be by Claudio, Canterbury, the Nurse, Ophelia, and Cymbeline.

Gower. The good in conversation, To whom I give my benison, Is still at Tarsus, where each man Thinks all is writ he speken can.

Pericles, Act ii.

Men. I think the policy of that purpose made more in the marriage than in the love of the parties.

Eno. I think so too. But you shall find, the band that seems to tie their friendship together will be the very strangler of their amity: Octavia is of a holy, cold, and still conversation.

Antony and Cleopatra, Act ii. Sc. 6.

The word conversation in these passages signifies conduct or behaviour, and in this sense it is used in some of the ancient statutes. 
Albeit that sithen the beginning of this present Parliament, good and honourable ordinances and statutes have been made and established for elections, presentations, consecrations, and investing of archbishops and bishops of this realm, and in all other the King's dominions, with all ceremonies appertaining unto the same, as by sundry statutes thereof made more at large is specified; yet, nevertheless, no provision hitherto hath been made for suffragans, which have been accustomed to be had within this realm, for the more speedy administration of the sacraments, and other good, wholesome and devout things and laudable ceremonies, to the increase of God's honour, and for the commodity of good and devout people. Be it therefore enacted by authority of this present Parliament, that every archbishop and bishop of this realm, and of Wales, and elsewhere within the King's dominions, being disposed to have any suffragan, shall and may at their liberties name and elect, that is to say, every of them for their peculiar diocese, two honest and discreet spiritual persons, being learned and of good conversation, \&c.-26 Henry VIII., cap. 14.

Where there hath been a very godly order set forth by the authority of Parliament, for common prayer and administration of the sacraments to be used in the mother tongue within the Church of England, agreeable to the word of God and the primitive Church, very comfortable to all good people desiring to live in Christian conversation and most profitable to the estate of this realm, upon the 
which the mercy, favour, and blessing of Almighty God is in no wise so readily and plenteously poured as by common prayer, due using of the sacraments, and often preaching of the Gospel, with the devotion of the hearers; and yet this notwithstanding a great number of people in divers parts of this realm, following their own sensuality, and living either without knowledge or due fear of God, do wilfully and damnably before Almighty God abstain and refuse to come to their parish churches and other places where common prayer, administration of the sacraments, and preaching of the word of God, is used upon Sundays and other days ordained to be holydays.

II. For reformation hereof, be it enacted that from and after the feast of All Saints next coming all and every person and persons inhabiting within this realm, or any other the King's Majesty's dominions, shall diligently and faithfully (having no lawful or reasonable excuse to be absent) endeavour themselves to resort to their parish church or chapel accustomed; or upon reasonable let thereof, to some usual place where common prayer and such service of God shall be used in such time of let, upon every Sunday and other days ordained and used to be kept as holydays; and then and there to abide orderly and soberly during the time of common prayer, preachings, and other service of God there to be used and ministered; upon pain of punishment by the censures of the Church. $-5 \& 6$ Edward VI., cap. i. 
Rom. With love's light wings did I o'er-perch these walls;

For stony limits cannot hold love out, And what love can do that dares love attempt; Therefore thy kinsmen are no let to me. Romeo and Juliet, Act ii. Sc. 2.

Burgundy. Which to reduce into our former favour

You are assembled: and my speech entreats That I may know the let, why gentle Peace Should not expel these inconveniences And bless us with her former qualities.

$$
\text { Henry V., Act v. Sc. } 2 .
$$

Mal. They have here propertied me; keep me in darkness, send ministers to me, asses, and do all they can to face me out of my wits.

Clo. Advise you what you say; the minister is here. Malvolio, Malvolio, thy wits the heavens restore! endeavour thyself to sleep, and leave thy vain bibble babble.

Twelfth Night, Act iv. Sc. 2.

'Let,' a noun in these passages and this statute. 'Endeavour themselves,' a common expression in the old Acts.

Kent. Good King, that must approve the common saw,

Thou out of heaven's benediction comest

To the warm sun! 
Approach thou beacon to this under globe, That by thy comfortable beams I may Peruse this letter!

Lear, Act ii. Sc. 2.

Hector. There is no lady of more softer bowels, More spongy to suck in the sense of fear, More ready to cry out 'Who knows what follows?' Than Hector is: the wound of peace is surety, Surety secure; but modest doubt is call'd The beacon of the wise, the tent that searches To the bottom of the worst.

Troilus and Cressida, Act ii. Sc. 2.

Enter LA Pucelle on the top, thrusting out a torch burning.

Puc. Behold, this is the happy wedding torch That joineth Rouen unto her countrymen, But burning fatal to the Talbotites!

Bast. See, noble Charles, the beacon of our friend;

The burning torch in yonder turret stands.

Char. Now shine it like a comet of revenge, A prophet to the fall of all our foes!

1 Henry VI., Act iii. Sc. 2.

Per. Lord governor, for so we hear you are, Let not our ships and number of our men Be like a beacon fired to amaze your eyes. Pericles, Act i. Sc. 4. 
Beacon. This word (says Coke), is derived of the Saxon word beacon, i. speculum, unde speculantur adventus hostium, and is often called signum speculatum, and bechan in the Saxon language is signum dare, and we use the word to beckon to at this day. Before the reign of Edward III. there were but stacks of wood set upon high places, which were fired when the comming of enemies were descried; but in his reign pitch boxes, as now they be, were instead of those stacks of wood set up, and this properly is a beacon. Light-houses, ignes speculatorii, seu monitorii, seu lumen maritimum, seu pharus, unde versus,

Lumina noctivagæ tollit pharus æmula lunæ. These light-houses are properly to direct seafaring men in the night when they cannot see marks, and these are also signa speculatoria.

Sea-marks, as steeples, churches, castles, trees, and such like, for direction of seafaring men in the day time, and these are called signa marina or speculatoria, or signa nautis.

So as you may divide specula or signa speculatoria or signa nautis into three branches, viz. into beacons, light-houses, and sea-marks. At the common law none but the King only could erect any of these three, which ever was done by the King's commission under the great seal ; as taking few examples for many.

De signis super montes per ignem faciend'

De signis super montes faciend.' 
Rex assignavit Henricum Epu' Norwic' et Willielmum comitem Suff. et alios, \&c. (inter alia), ad signa speculatoria super montes in com' Norf. ponend. Et similes commissiones in aliis comitatibus. -4 Coke cap. xxv.

Falstaff. The second property of your excellent sherris is, the warming. of the blood; which, before cold and settled, left the liver white and pale, which is the badge of pusillanimity and cowardice; but the sherris warms it and makes it course from the inwards to the parts extreme: it illumineth the face, which as a beacon gives warning to all the rest of this little kingdom, man, to arm; and then the vital commoners and inland petty spirits muster me all to their captain, the heart, who, great and puffed up with this retinue, doth any deed of courage; and this valour comes of sherris.

2 Henry IV., Act iv. Sc. 3.

Biron. A wighty wanton with a velvet brow, With two pitch-balls stuck in her face for eyes; Ay, and, by heaven, one that will do the deed, Though Argus were her eunuch and her guard: And I to sigh for her! to watch for her! To pray for her !

Love's Labour Lost, Act iii. Sc. 1.

Coke says that beacons were fired when the coming of enemies was descried, and Falstaff says that 'Sherris illumineth the face, which, 
as a beacon, gives warning to all the rest of this little kingdom, man, to arm.' And Biron may, in this line,

With two pitch-balls stuck in her face for eyes, refer to the pitch which was used in Shakespeare's time for beacons.

Kent. Sir, I do know you; And dare, upon the warrant of my note, Commend a dear thing to you. There is division, Although as yet the face of it be cover'd With mutual cunning, 'twixt Albany and Cornwall; Who have-as who have not, that their great stars Throned and set high ?-servants, who seem no less, Which are to France the spies and speculations Intelligent of our state.

\section{Lear, Act iii. Sc. 1.}

Corn. Leave him to my displeasure. Edmund, keep you our sister company: the revenges we are bound to take upon your traitorous father are not fit for your beholding. Advise the duke, where you are going, to a most festinate preparation; we are bound to the like. Our posts shall be swift and intelligent betwixt us.

Lear, Act iii. Sc. 7.

I think the word speculation used by Kent in this passage is the signa speculatoria Coke 
speaks of, which was set upon high places to direct seafaring men in the night, when they could not see. And although the servants described as spies and speculations were not throned and set on high, yet those, whose great stars had throned them and set them on high, had servants who were to France spies and speculations intelligent of the state.

Queen Margaret. Richard yet lives, hell's black intelligencer.

Richard III., Act iv. Sc. 4.

Lancaster. Who hath not heard it spoken How deep you were within the books of God? To us the speaker in his parliament;

To us the imagined voice of God himself;

The very opener and intelligencer

Between the grace, the sanctities of heaven And our dull workings.

2 Henry IV., Act iii. Sc. 2.

For the better discovery and avoiding such traiterous and most dangerous conspiracies and attempts as are daily devised and practised against our most gracious Sovereign Lady the Queen's Majesty, and the happy estate of this common weal, by sundry wicked and seditious persons, who terming themselves Catholics, and being indeed spies and intelligencers, not only for Her Majesty's foreign enemies, 
but also for rebellious and traiterous subjects born within Her Highness' realms and dominions, and biding their most detestable and develish purposes under a false pretext of religion and conscience, do secretly wander and shift from place to place within this realm, to corrupt and seduce Her Majesty's subjects, and to stir them to sedition and rebellion.35 Elizabeth, cap. 2.

\section{CXVI.}

Let me not to the marriage of true minds Admit impediments. Love is not love Which alters when it alteration finds, Or bends with the remover to remove : $\mathrm{O}$, no! it is an ever-fixed mark That looks on tempests and is never shaken;

It is the star to every wandering bark, Whose worth's unknown, although his height be taken.

Lore's not Time's fool, though rosy lips and cheeks Within his bending sickle's compass come ;

Love alters not with his brief hours and weeks, But bears it out even to the edge of doom.

If this be error and upon me proved,

I never writ, nor no man ever loved.

Sonnett.

Coriolanus. The god of soldiers,

With the consent of supreme Jove, inform

Thy thoughts with nobleness; that thou mayest prove

To shame unvulnerable, and stick i' the wars 
Like a great sea-mark, standing every flaw, And saving those that eye thee!

Act v. Sc. 3 .

The word sea-mark, used by Coriolanus, signifies something set up near the sea for the direction of seafaring men, and in this sense it is used in the 8 Elizabeth, cap. xiii., which recites and enacts as follows:-

Per. Sir, my gracious lord, To chide at your extremes it not becomes me: O, pardon, that I name them! Your high self, The gracious mark o' the land, you have obscured With a swain's wearing, and me, poor lowly maid, Most goddess-like prank'd up : but that our feasts In every mess have folly and the feeders Digest it with a custom, I should blush To see you so attired, sworn, I think, To show myself a glass.

Winter's Tale, Act iv. Sc. 4.

Whereas the master, wardens and assistants of the Trinity House of Deptford-Strond, being a company of the chiefest and most expert masters and governors of ships, incorporate with themselves, charged with the conduction of the Queen's Majesty's Navy Royal, are bound to foresee the good increase and maintenance of ships, and of all kind of men traded and brought up by water craft, most meet for her Majesty's marine service. And 
forasmuch as by destroying and taking away of certain steeples, woods and other marks, standing upon the main shores, adjoining to the sea coasts of this realm of England and Wales, being as beacons and marks of ancient time accustomed for seafaring men, to save and keep them and the ships in their charge from sundry dangers thereto incident: divers ships with their merchandizes, in sailing from foreign parts towards this realm of England and Wales, and especially to the river and port of Thames, have by the lack of such marks of late years been miscarried, perished, and lost in the sea, to the great detriment and hurt of the common weal, and the perishing of no small number of people.

II. For remedy wherein to be had, be it enacted, established, and ordained by the Queen's most excellent Majesty, by the consents of the Lords Spiritual and Temporal, and the Commons, in this present Parliament assembled, and by the authority of the same, that the aforesaid masters, wardens, and assistants of the Trinity House at Deptford-Strond aforesaid, being a company incorporated as before, shall and may lawfully, by virtue of this Act, from time to time hereafter, at their wills and pleasures, and at their costs, make, erect, and set up such and so many beacons, marks, and signs for the sea, in such place or places of the sea shores, and uplands near the sea coasts or forelands of the sea, only for sea-marks, as to them shall seem most meet, needful, and requisite, whereby the dangers may be avoided and 
escaped, and ships the better come to their ports without peril.

III. And that all such beacons, marks, and signs, so to be by them or their assigns erected, made, and set up, at the costs and charges of the said master, wardens, and assistants, shall and may be continued, renewed, and maintained from time to time, at the costs and charges of the said master, wardens, and assistants; anything to the contrary hereof notwithstanding.

IV. And be it further ordained and enacted by the authority aforesaid, that no steeples, trees, or other things now standing as beacons or marks for the sea, whereof to the owner or occupier of the place where the same doth grow or stand, before the first day of March next coming notice shall be given by the Queen's Majesty's Letters under her signet, shall at any time hereafter be taken down, felled, or otherwise cut down, upon pain that every person by whose procurement or consent such offence shall be committed shall forfeit the sum of one hundred pounds, whereof the one moiety to the Queen's Majesty, and the other moiety to be to the master, wardens, and assistants of the said Trinity-house. And if the said person or persons so offending be not of the value of one hundred pounds, then the same person and persons to be deemed convict of outlawry ipso facto, to all constructions and purposes. 
Othello. Be not afraid, though you do see me weapon'd:

Here is my journey's end, here is my butt, And very sea-mark of my utmost sail.

Act v. Sc. 2.

But I think that Othello uses the word seamark to signify an end or termination, for as the butt of which he speaks is the mark at which the arrow stops, or ought to stop, so the sea-mark is the mark which the sea makes on the shore, the point beyond which no ship can sail; and in this sense it is used in the 7 James I. cap. xvii., which enacts that 'it shall and may be lawful to and for all persons whatsoever resiant and dwelling within the counties of Devon and Cornwall, to fetch and take the sea-sand at all places under the full sea-mark, where the same is or shall be cast by the sea, for the bettering of their land, and for the increase of corn and tillage, at their wills and pleasures.'

Weaponed; this word is used in the preamble of the 39 Elizabeth, cap. xvii.

Whereas divers lewd and licentious persons, contemning both laws, magistrates, and religion, have 
of late days wandered up and down in all parts of this realm, under the name of soldiers and mariners, abusing the title of that honourable profession to countenance their wicked behaviours, and do continually assemble themselves weaponed in the highways and elsewhere, in troops, to the great terror and astonishment of her Majesty's true subjects, the impeachment of her laws, and the disturbance of the peace and tranquillity of this realm : and whereas many heinous outrages, robberies, and horrible murders are daily committed by these dissolute persons; and unless some speedy remedy be had, many damages are like by these means to ensue and grow towards the commonwealth. - 39 Elizabeth, cap. xvii.

Biondello. Take the priest, clerk, and some suffcient honest witnesses.

The Taming of the Shrew, Act iv. Sc. 4.

If any party at any time hereafter, for any matter or cause before rehearsed, limited, or appointed by this Act, to be sued or determined in the King's Ecclesiastical Court, or before the ecclesiastical judge, do sue for any prohibition in any of the King's courts where prohibitions before this time have been used to be granted, that then in every such case the same party, before any prohibition shall be granted to him or them, shall bring and deliver to the hands of some of the justices or judges of the same court where such party demandeth the prohibition, the very true copy of the libel depending in the eccle- 
siastical court, and concerning the matter wherefore the party demandeth the prohibition, subscribed or marked with the hand of the same party; and under the copy of the said libel shall be written the suggestion whereof the party so demandeth the said prohibition; and in case the said suggestion, by two honest and sufficient witnesses at the least, be not proved true in the court where the said prohibition shall be granted, within six months next following after the said prohibition shall be so granted and awarded, that then the party that is letted or hindered of his or their suit in the ecclesiastical court by such prohibition, shall, upon his or their request and suit, without delay, have a consultation in the same case in the court where the said prohibition was granted. $-2 \& 3$ Fdward VI., cap. xiii. sec. 14 .

In their most humble and dutiful wise shewen and beseechen your Highness, your true and faithful subjects, the clothiers, merchants, and chapmen of your county of Devon, and of the counties adjoining, that where in the month of January, in the four and thirtieth year of your Majesty's most happy reign, as well as the humble suit and petition of sundry of your said subjects, as upon certificate of divers justices in your Highness said county of Devon, and upon complaint of the States of Holland, it pleased your Highness, with the advice of your mosthonourable Privy Council, by your Highness proclamation for the reformation of the insufficiencies 
grown in the clothes called Devonshire kersies, or dozens (a commodity heretofore in great request, price, and estimation, both amongst your natural subjects and in foreign nations and countries), but of late marvelously (and not without occasion) discredited by the inventions and new devices of the weavers, tuckers, and artificers, to command that the laws before that time made, and standing in force not repealed, for and concerning the premises, should be duly accomplished in all things; and that every officer should diligently perform his office accordingly; and that the weight of the said kersies, or dozens, being raw, and wrought with clean stuff, without any deceitful addition, should weigh fifteen pounds, and contain in the market at least fifteen and sixteen yards in length, and that the same should be sewantly woven throughout of like sorted yarn, forbidding all other deceits in weaving, and all diminishing and unreasonable drawing, stretching, and other deceits in tuckers; and that each weaver should weave his shop-mark in each dozen, and a purrel in each end thereof; and that officers should be appointed in market towns to view, weigh, and try the same kersies, whether they were in length, weight, or goodness, according to the rate and proportion set forth in the same proclamation : the same proclamation to endure till the first day of this present Parliament, as by the same more at large may appear. Now, Most Gracious Sovereign, forasmuch by the proclamation, great order and better making of the said clothes for 
weight and length thereof hath ensued, and to the end that hereafter further discovery and restraint of all abuses and deceits contrary to former laws and statutes of this realm may be provided for, to the reviving of the reputation of so good, profitable, and necessary commodity, it may please your Majesty, with the assent of the Lords Spiritual and Temporal, and the whole commonalty assembled in this present Parliament, and by the authority of the same, that it may be enacted and established as followeth, that is to say - 'That from and after the first day of July now next coming, each kersie called Devonshire kersie, or dozen, which shall be made and woven within the said county of Devon, or any other county next adjoining thereunto, being raw, unscoured, untucked, and unwet, as it cometh from the weaver's beam, and being made of clean and perfect stuff, that is, to wit, of wool, shorn, cleansed, and thoroughly washed or scoured after the shearing, and before the weaving, without any fraud, deceit, policy, or device, or any stuff thereunto deceitfully or unlawfully added in the working or after the working thereof for increase of the weight, shall weigh in the market fifteen pounds or upwards.'-35 Elizabeth, cap. x.

It is evident that in Shakespeare's time Devonshire kersies, or dozens, were in great estimation, for according to the proclamation recited in the preamble of this statute, Devonshire kersies, or dozens, are said to be a com- 
modity heretofore in great request, price, and estimation, both amongst Queen Elizabeth's natural subjects and in foreign nations and countries :-

Fal. Go to, I know you well enough.

Host. No, Sir John; you do not know me, Sir John. I know you, Sir John: you owe me money, Sir John; and now you pick a quarrel to beguile me of it: I bought you a dozen of shirts to your back.

Fal. Dowlas, filthy dowlas: I have given them away to bakers' wives, and they have made bolters of them.

Host. Now, as I am a true woman, holland of eight shillings an ell. You owe money here besides, Sir John, for your diet and by-drinkings, and money lent you, four and twenty pound.

1 Henry IV., Act iii. Sc. 3.

And I think that Shakespeare, in this passage, plays upon the word dozen, for although the Hostess may use the word to signify only the number twelve, yet Falstaff seems to answer her as if he accepted the word in the sense in which it is used in this statute; and also to decry it by calling the dozen 'dowlas, filthy dowlas,' which was an inferior kind of cloth. The 28 Henry VIII., cap. iv., which recites and repeals the 21 Henry VIII., cap. xiv., 
concerning dowlas and lockram, enacts that ' no manner of person, English nor stranger, denizen nor alien, shall put to sale any whole piece or half piece of the said linen cloth, called dowlas and lockrams, unless there be mention expressed upon every of the said whole piece or half piece of the said linen cloth, and called dowlas or lockram, so put to sale, as is aforesaid, the whole and entire number of the yards or ells that is contained in every such whole piece or half piece, upon pain of forfeiture of the same whole piece or half piece not containing the number of yards or ells so mentioned upon every of the said whole piece or half piece so put to sale as is aforesaid :' \&c.

Bru. All tongues speak of him, and the bleared sights

Are spectacled to see him : your prattling nurse Into a rapture lets her baby cry While she chats him: the kitchen malkin pins Her richest lockram 'bout her reechy neck, Clambering the walls to eye him.

Coriolanus, Act ii. Sc. 1.

From these statutes it is evident that the Devonshire kersie, or dozen, was made of 
'clean and perfect stuff, that is, of wool, shorn, cleansed, and thoroughly washed or scoured after the shearing, and that it would contrast advantageously with what Falstaff calls filthy dowlas. Dowlas and lockram were linen cloth which was made of flax or hemp, and worn by the common people; therefore Brutus says, 'The kitchen malkin pins her richest lockram about her reechy neck.'

Bap. Who comes with him?

Bion. O, sir, his lackey, for all the world caparisoned like the horse; with a linen stock on one leg and a kersey boot-hose on the other, gartered with a red and blue list.

Taming of the Shrew, Act iii. Sc. 2.

First Gent. Well, there went but a pair of shears between us.

Lucio. I grant; as there may between the lists and the velvet. Thou art the list.

First Gent. And thou the velvet: thou art good velvet; thou 'rt a three-piled piece, I warrant thee : I had as lief be a list of an English kersey as be piled, as thou art piled, for a French velvet.

Measure for Measure, Act i. Sc. 2.

A portion of the fourth section of the 35 Elizabeth, cap. x., will serve to explain the meaning of the word 'list' in these passages :- 
' No weaver shall use any diversity in the bigness or goodness of his yarn in any part of the said kersies, saving only in the lists, nor use any other practice in edging or weaving of any of the same kersies, or dozens, to make the same seem finer near the edge or lists than in any other part of the same cloth.'

Biondello says the lackey is gartered with a red and blue list, and I think that Shakespeare means that he wore garters which were made with the edge or lists of woollen cloth, which are at the present day often of a blue or red colour, and very generally used, amongst the poorer classes at least, for making garters.

And. O, be persuaded! do not count it holy To hurt by being just : it is as lawful, For we would give much, to use violent thefts, And $r o b$ in the behalf of charity.

Troilus and Cressida, Act v. Sc. 3.

Violent thefts. Robbery was sometimes called violent theft by the old law writers.

'Robbery (says Coke) is a felony by the common law, committed by a violent assault upon the person of another, by putting him in fear, and taking from his person his money or other goods of any value whatsoever.'-3 lnst., cap. xvi. 
The reader will see that Shakespeare uses the verb 'rob' in connection with the words 'violent theft,' and as Coke says 'the violent assault (committed in robbery) agreeth with the indictment, violenter et felonice cepit.'

This is sometimes called violent theft.West Simbol, which is felony of two-pence.Kitchen, fol. 16, and 22, lib. s., 39. See Skene de verborum. Signif. Verb. Reif., and Cromp._Justice of Peace, fol. 30.

- Of this word robbery (says Coke) it is derived de la Robe, both because in antient times (as sometimes yet is done) they bereave the true man of some of his robes or garments, and also for that his money or other goods are taken from his person-that is, from or out of some part of his garment or robe about his person: and is ranked in this place, for that it concerneth not only the goods, but the person of the owner.'-3 Inst., cap. xvi.

Gads. Give me thy hand: thou shalt have a share in our purchase, as I am a true man.

Cham. Nay, rather let me have it, as you are a false thief.-1 Henry IV., Act ii. Sc. 1 .

$D o g$. If you meet a thief, you may suspect him, by virtue of your office, to be no true man; and, for such kind of men, the less you meddle or make with them, why, the more is for your honesty.

Much Ado About Nothing, Act ii. Sc. 3. 
Prince. The thieves have bound the true men. Now could thou and I rob the thieves and go merrily to London; it would be argument for a week, laughter for a month, and a good jest for ever.

\section{Henry IV., Act ii. Sc. 2.}

Clif. Ay, ay, so strives the woodcock with the gin!

North. So doth the cony struggle in the net.

York. So triumph thieves upon their conquer'd booty!

So true men yield, with robbers so o'ermatch'd.

$$
3 \text { Henry VI., Act i. Sc. } 1 .
$$

Fal. Poins! Now shall we know if Gadshill have set a match. $O$, if men were to be saved by merit, what hole in hell were hot enough for him? This is the most omnipotent villain that ever cried 'Stand' to a true man.

1 Henry IV., Act. i. Sc. 2.

The words of the indictment be, violenter et felonice cepit. Hic opus est interprete. For it must be understood that there is an actual taking in deed, and a taking in law, and that may be when a thief receiveth, \&c. For example: if thieves rob a true man, and find but little about him, take it, this is an actual taking; and by means of death compel him to swear upon a book to fetch them a greater sum, which he doth, and deliver it unto them, which they receive, this is a taking in law by them and adjudged robbery : for fear made him to take the 
oath, and the oath and fear continuing, made him bring the money, which amounteth to a taking in law; and in this case there need no special indictment, but the general indictment (quod violenter et felonice cepit) is sufficient; and so it is, if at the first the true man for fear deliver his purse, \&c., to the thief. -3 Inst., c. xvi.

\section{Ant. Now I must}

To the young man send humble treaties, dodge And palter in the shifts of lowness; who With half the bulk o' the world play'd as I pleased, Making and marring fortunes.

Antony and Clenpatra, Act iii. Sc. 9.

Most humbly beseecheth the Queen's most excellent highness, your loving and obedient subjects, the Commons in this your present Parliament assembled: that where by reason of divers sundry licences heretofore granted to divers persons, as well within the city of London and the suburbs of the same, as also in divers places within your highness's realm, for the having, maintaining, and keeping of houses, gardens, and places for bowling, tennis, dicing, white and black, making and marring, and other unlawful games prohibited by the laws and statutes of this realm, divers and many unlawful assemblies, conventicles, seditions, and conspiracies have been daily secretly practised by idle and misruled persons repairing to such places, of which robberies and many other misdemeanors have ensued 
to the breach of your Highness's peace; for remedy whereof it may please your Highness that it may be enacted by your Highness, the Lords Spiritual and Temporal, and the Commons, in this present Parliament assembled, that, from and after the Feast of the Birth of our Lord now next coming, every licence, placard, or grant made to any person or persons for the having, maintenance, or keeping of any bowling-allies, dicing-houses, or other unlawful games prohibited by the laws and statutes of this realm, shall be from the said feast utterly void and of none effect.-2 and 3 Philip and Mary, cap. ix.

Item pur tant qe diverses homicides, murdres, rapes, roberies \& autres felonies, riotes, conventicles \& malefaitz jatarde ount estez faitz en diverses countees dEngleterre par gentz neez en Irlande repararitz a la ville de Oxenford \& illoeges demurrantz desoutz la jurisdiction del universite dOxenford a grande peure de tout manere poeple demurrant la environ come par toute la communalte $d u$ Roialme assemblez en cest parlement fuist grevousment de ces compleint en le mesme le Roy del assent avaundit \& la requeste de mesme la communalte ad ordeinez qe toutz gentz neez en Irland soient voidez hors de Roialme dedeins le mois procheine apres le proclamation faite de ceste ordinance sur peine de perdre lour beins \& destre emprisonez a la voluntee de Roy.-1 Henry IV., cap. 3 .

'Voidez hors de Roialme,' depart out of the realm. 
K. Hen. I was not angry since I came to France Until this instant. Take a trumpet, herald; Ride thou unto the horsemen on yon hill: If they will fight with us, bid them come down, Or void the field; they do offend our sight. Henry V., Act iv. Sc. 7.

The verb 'void' is used in this passage in the same sense, signifying 'to depart out of, or leave.' 'The word is used also in the 2 Henry VI., cap. ix.

Glo. And you, my sovereign lady, with the rest,

Causeless have laid disgraces on my head And with your best endeavour have stirr'd up My liefest liege to be mine enemy:

Ay, all of you have laid your heads togetherMyself had notice of your conventiclesAnd all to make away my guiltless life.

$$
2 \text { Henry VI., Act iii. Sc. } 1 .
$$

The word conventicle is a term often, if not usually, applied to a meeting of dissenters from the Established Church, as it is in the 35 Elizabeth, cap. i.; but in these statutes, and also in the 2 Henry IV. cap. xv., it has a different meaning, signifying a secret assembly 
of persons who conspire together to act unlawfully; and it is evidently used in this sense by Gloster.

K. John. What earthly name to interrogatories Can task the free breath of a sacred king? Thou canst not, cardinal, devise a name So slight, unworthy and ridiculous, To charge me to answer, as the pope. Tell him this tale; and from the mouth of England Add thus much more, that no Italian priest Shall tithe or toll in our dominions ; But as we, under heaven, are supreme head, So under Him that great supremacy, Where we do reign, we will alone uphold, Without the assistance of a mortal hand: So tell the pope, all reverence set apart 'To him and his usurp'd authority.

Act iii. Sc. 1.

Prince Henry. My gracious lord! my father! This sleep is sound indeed; this is a sleep That from this golden rigol hath divorced So many English kings. Thy due from me Is tears and heavy sorrows of the blood, Which nature, love, and filial tenderness, Shall, O dear father, pay thee plenteously: My due from thee is this imperial crown, Which, as immediate from thy place and blood, Derives itself to me.

2 Henry IV., Act iv. Sc. 4. 
Alas, poor women! make us but believe,

Being compact of credit, that you love us :

The Comedy of Errors, Act iii. Sc. 2.

Duke S. If he, compact of jars, grow musical, We shall have shortly discord in the spheres. As You Like It, Act ii. Sc. 7.

The lunatic, the lover, and the poet Are of imagination all compact : Midsummer Night's Dream, Act v. Sc. 1.

Cant. Therefore doth heaven divide The state of man in divers functions, Setting endeavour in continual motion ; To which is fixed, as an aim or butt, Obedience; for so work the honey-bees, Creatures that by a rule in nature teach The act of order to a peopled kingdom. They have a king and officers of sorts; Where some, like magistrates, correct at home, Others, like merchants, venture trade abroad, Others, like soldiers, armed in their stings, Make boot upon the summer's velvet buds, Which pillage they with merry march bring home To the tent-royal of their emperor; Who, busied in his majesty, surveys The singing masons building roofs of gold, The civel citizens kneading up the honey, The poor mechanic porters crowding in Their heavy burdens at his narrow gate, 
The sad-eyed justice, with his surly hum, Delivering o'er to executors pale The lazy yawning drone.

Henry V., Act i. Sc. 2.

Where by divers sundry old authentick histories and chronicles, it is manifestly declared and expressed, that this realm of England is an Empire, and so hath been accepted in the world, governed by one supreme head and king, having the dignity and royal estate of the imperial crown of the same; unto whom a body politick, compact of all sorts and degrees of people, divided in terms, and by names of spiritualty and temporalty, been bounden and owen to bear, next to God a natural and humble obedience.-24 Henry VIII., cap. 12.

By 25 Henry VIII., cap. xxi., Elizabeth, cap. i., and James, cap. i., the crown of this kingdom is affirmed to be an imperial crown.-4 Inst. 343 .

\section{The preamble of the 25 Henry VIII., cap.} xxi., concludes with these words:-

And because that it is now in these days seen, that the state, dignity, superiority, reputation and authority of the said imperial crown of this realm, by the long sufferance of the said unreasonable and uncharitable usurpations and exactions practised in the times of your most noble progenitors, is much and sore decayed and diminished, and the people of this realm thereby impoverished, and so or worse be like to continue, if remedy be not therefore shortly provided. 
First Clown. Your water is a sore decayer of your whoreson dead body.

\section{Hamlet, Act v. Sc. 1.}

King. I like him not, nor stands it safe with us To let his madness range. Therefore prepare you; I your commission will forthwith despatch, And he to England shall along with you : The terms of our estate may not endure Hazard so dangerous as doth hourly grow Out of his lunacies.

Guil. We will ourselves provide: Most holy and religious fear it is To keep those many many bodies safe That live and feed upon your majesty.

Ros. The single and peculiar life is bound, With all the strength and armour of the mind, To keep itself from noyance; but much more That spirit upon whose weal depend and rest The lives of many. The cease of majesty Dies not alone; but, like a gulf, doth draw What's near it with it: it is a massy wheel, Fix'd on the summit of the highest mount, To whose huge spokes ten thousand lesser things Are mortised and adjoin'd; which, when it falls, Each small annexment, petty consequence, Attends the boisterous ruin. Never alone Did the king sigh, but with a general groan.

Hamlet, Act iii. Sc. 3.

Shakespeare may refer in this passage to 
the preamble of the 5 and 6 Edward VI., cap. xi., which runs thus:-

For as much as it is most necessary, both for common policy and duty of subjects, above all things to prohibit, restrain and extinct all manner of shameful slanders which might grow, happen or arise to their Sovereign Lord the King's Majesty, which when they be heard, seen or understand, cannot be but edible, and also abhorred of all those sorts that be true and loving subjects, if in any point they may, do, or shall touch his Majesty, upon whom dependeth the whole unity and universal weal of this realm, without providing wherefore too great a scope of unreasonable liberty should be given to all cankered and traiterous hearts, and the king's loving subjects should not declare unto the Sovereign Lord now being, which unto them hath been and is most entirely, both beloved and esteemed, their undoubted sincerity and truth. Be it therefore enacted, \&c.

Rosencrantz speaks of that spirit, 'upon whose weal depend and rest the lives of many;' and says besides 'the cease of majesty dies not alone.' And this preamble speaks of 'his Majesty, upon whom dependeth the whole unity and universal weal of this realm.' Shakespeare not only gives the same idea of majesty and its dependencies which is contained in this preamble, but he uses the same words with 
which that idea is expressed. In the folio we read:

That spirit, upon whose spirit depend and rest The lives of many.

In the quarto:-

That spirit upon whose weal depend and rest The lives of many.

King Henry. Canst thou, when thou command'st the beggar's knee,

Command the health of it? No, thou proud dream, That play'st so subtly with a king's repose; I am a king that find thee, and I know 'Tis not the balm, the sceptre and the ball, The sword, the mace, the crown imperial, The intertissued robe of gold and pearl, The farced title running 'fore the king, The throne he sits on, nor the tide of pomp That beats upon the high shore of this world, No, not all these, thrice gorgeous ceremony, Not all these, laid in bed majestical, Can sleep so soundly as the wretched slave, Who with a body fill'd and vacant mind Gets him to rest, cramm'd with distressful bread. Henry V., Act iv. Sc. 1.

' As the sceptre (says Selden) is the ornament of the right hand, so in the left the globe, or mound, 
with the cross infixed, in statues and pictures (and in some coronations) of kings, is a singular ensign of royal dignity. That which we name a globe or mound here is also sometimes called an apple, sometimes a ball. And it is observed by learned men that it was frequent in the State of Rome before the emperors were Christian, to have, both among their ensigns in the field and in their monies, the ball or globe, the beginning whereof Isidore also refers to Augustus. Pilam (saith he) in signa constituisse fertur Augustus, propter nationes sibi in cuncto orbe subjectas ut malus figuram orbis ostenderet: thus some copies have it, and not magis figuram, \&c., as we usually read there. But Lipsius reads malis out of some MSS., and Theodorus Dowza, imagine in that of Isidore. However, it seems that to this purpose pila and malus, or a ball and apple, are as synonymies, and denote the figure of the earth as well in the field on a lance as on their coins ; sometimes in the hand of Victory, sometimes of Fortune or otherwise. But afterwards, when the holy cross came into estimation, and was received with such reverence by the emperors into their ensigns, it was added also to this globe or apple held in the hands of their pictures or statues-sometimes in the left, sometimes in the right. In England, almost all the kings, down from Edward the Confessor inclusively to this day, have it in their left hands on their seals or coins; and we see the like everywhere in their statues and pictures that show the form of their coronations, or preparation for burials. But I 
have at the end of an old MS. ordo coronationis, the form of a preparation for the burial of a king, where I have the shape of him in his royal robes, crowned and holding a sceptre in his right hand, and with this globe or with the cross in the left. But the direction that is written with this shape puts it in the right. But if we might trust to the eredit of that seal attributed to King Arthur, which Leland says he saw in Westminster Church, we should find it as ancient in the hands of the kings of this land almost as of the old emperors. He says King Arthur in that seal had in his right hand a sceptre, fleurie de lis on the top, and in his left hand orbem cruce insignitum.'-Titles of Honour, First Part.

\section{And York says :-}

York. From Ireland thus comes York to claim his right,

And pluck the crown from feeble Henry's head:

Ring, bells, aloud ; burn, bonfires, clear and bright, To entertain great England's lawful king.

Ah! sancta majestas, who would not buy thee dear?

Let them obey that know not how to rule ;

This hand was made to handle nought but gold.

I cannot give due action to my words,

Except a sword or sceptre balance it:

A sceptre shall it have, have I a soul,

On which I'll toss the flower-de-luce of France.

$$
2 \text { Henry VI., Act v. Sc. } 1 .
$$


King. Make thy demand.

Hel.

But will you make it even?

King. Ay, by my sceptre and my hopes of heaven. All's Well That Ends Well, Act. ii. Sc. 1.

King.

For all the world

As thou art to this hour was Richard then When I from France set foot at Ravenspurgh, And even as I was then is Percy now. Now, by my sceptre and my soul to boot, He hath more worthy interest to the State Than thou the shadow of succession.

1 Henry IV., Act iii. Sc. 2.

K. Rich. Mowbray, impartial are our eyes and ears ;

Were he my brother, nay, my kingdom's heir, As he is but my father's brother's son, Now, by my sceptre's awe, I make a vow, Such neighbour nearness to our sacred blood Should nothing privilege him, nor partialize The unstooping firmness of my upright soul: $\mathrm{He}$ is our subject, Mowbray, so art thou : Free speech and fearless $I$ to thee allow.

Richard II., Act i. Sc. 1.

- Aristotle says that, in heroic times, some kings were sworn, others not. But the oath of them that

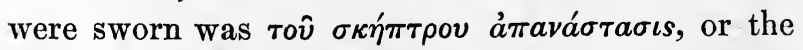
lifting up of the sceptre, which was called, therefore, ö $\rho к \iota \nu ~ \sigma \kappa \hat{\eta} \pi \tau \rho o \nu$, or the oath sceptre; and 
therefore also doth Homer make Achilles swear by his sceptre-

Naì $\mu \grave{a} \tau o ́ \delta \varepsilon \sigma \kappa \hat{\eta} \pi \tau \rho o \nu-$

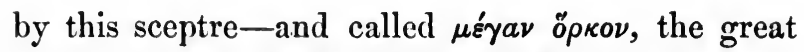
oath.'-Selden, 'Titles of Honour, First Part.

Jaq. God give you good morrow, master Parson. Hol. Master Parson, quasi pers-on. An if one should be pierced, which is the one?

Cost. Marry, master schoolmaster, he that is likest to a hogshead.

Hol. Piercing a hogshead! a good lustre of conceit in a tuft of earth; fire enough for a flint, pearl enough for a swine: 'tis pretty; it is well.

Jaq. Good master Parson, be so good as read me this letter: it was given me by Costard, and sent me from Don Armado; I beseech you, read it.

Love's Labour Lost, Act iv. S'c. 2.

' Eodem modo sicut persona alicujus ecclesiæ recuperare potest communiam pasturæ per breve novæ disseisionæ, eodem modo de cætero recuperet successor super disseisitorem vel ejus heredem per breve, quod permittat, licet hujusmodi breve prius in cancellaria non fuerit concessum.'-13 Edward I., cap. xxiv.

' In like manner as a parson of a church may recover common of pasture by writ of novel disseisin, likewise from henceforth his successor shall have a 
quod permittat against the disseisor or his heir, though a like writ were never granted out of the Chancery before.'

'Parson, persona, in the legal signification, is taken for the rector of a church parochial, and is called persona ecclesia, because he assumeth and taketh upon him the person of the church, and is said to be seised in jure ecclesix, and the law had an excellent end therein, viz. that in his person the church might sue for and defend her right, and also be sued by any that had an elder and better right; and when the church is full, it is said to be plena et consulta of such a one parson thereof, that is, full and provided of a parson, that may vicem seu personam ejus gerere.'-Co. Litt., $300 \mathrm{~b}$.

' Or he is called parson as he is bound by virtue of his office in propria persona servire Deum.'Fleta, lib. ix. cap. 18.

Coriolanus. Aufidius, though I cannot make true wars,

I'll frame convenient peace.

Act v. Sc. 3 .

King. Have you perused the letters from the pope,

The emperor, and the earl of Armagnac?

Glou. I have, my lord; and their intent is this: They humbly sue unto your excellence 
To have a goilly peace concluded of

Between the realms of England and France.

King. How doth your grace affect their motion?

Glou. Well, my good lord; and as the only means

To stop effusion of our Christian blood And stablish quietness on every side.

1 Henry VI., Act v. Sc. 1.

King. Shall we buy treason? and indent with fears

When they have lost and forfeited themselves.

$$
1 \text { Henry IV., Act i. Sc. } 3 .
$$

Belarius. When on my three-foot stool I sit and tell

The warlike feats I have done, his spirits fly out Into my story.

Cymbeline, Act iii. Sc. 3 .

' Forasmuch as it is notoriously known that the King, to his great costs and charges, hath sent his ambassadors to Charles his adversary of France, to have had a convenient peace with him, and to have his right without effusion of Christian blood, which was refused; wherefore the King, by the grace of God, in whose hands and disposition resteth all victory, hath determined himself to pass over the sea into this realm of France, and to reduce possession thereof by the said grace to him, and to his heirs, kings of England, according to his rightful title, whereby he trusteth not only to bring this his realm 
to the ancient fame and honour, but also to enrich, and set in perfect peace and tranquillity his subjects of the same, trusting that thereby the more part of all Christian realms shall be in more perfect peace and tranquillity, and the better disposed to serve God: which cannot be done, by all likelihood, without battle, as on the sea as in other places beyond the sea, wherein Almighty God must be judge, in whose defence, mercy, and goodness the King putteth his full trust above all other things; howbeit many times, by the inordinate covetise of captains retained with princes afore this time, great part of the number of soldiers, for whom such captains have endented with princes, at time of need have lacked of their number of soldiers, whereby great jeopardies have ensued, and irrecuperable damages thereby may ensue, if remedy be not therefore foreseen and had. Be it therefore ordained by the authority of this present Parliament, that if any captain be retained, or hereafter shall be, to serve the King on the sea, or beyond the sea, in feat of war, which hath not his or their whole and perfect number of men and soldiers, according as he shall be retained with the king, or give not them their full wages without shorting as he shall receive of the King for them, except for jackets for them that receive land wages, that is to say, vis. viiid. for a yeoman, and xiiis. ivd. for a gentleman, for a whole year, he shall for such default forfeit to the King all his goods and chattels, and their bodies to prison.'-7 Henry VII., cap. i. 
Melun. Commend me to one Hubert with your king :

The love of him, and this respect besides, For that my grandsire was an Englishman, $A$ wakes my conscience to confess all this. In lieu whereof, I pray you, bear me hence From forth the noise and rumour of the field, Where I may think the remnant of my thoughts In peace, and part this body and my soul With contemplation and devout desires. King John, Act v. Se. 4.

Por. Yes, bring me word, boy, if thy lord look well,

For he went sickly forth: and take good note What Cresar doth, what suitors press to him. Hark, boy ! what noise is that?

Luc. I hear none, madam.

Por.

Prithee, listen well;

I heard a bustling rumour like a fray, And the wind brings it from the Capitol.

Julius Casar, Act ii. Sc. 4.

The word rumour in these passages signifies noise, disturbance, and in this sense it is often used in the ancient statutes.

Item, coment qa parlement tenuz a Westm' lan du regne nostre Seignur le Roi qore est quint pur ceo qe villeins et autres meffesours tard devaunt leverent par assemblees et outrageouse nombre en diverses parties de Roialme encontre la dignitee nostre 
Seignur le Roi et sa corone et les leies de sa terre defendu fuist par nostre Seignur le Roi estroitment a touz maners des gentz qe nul delors feroit ou recommenceroit tielx riot ou rumour nautres semblables; et si nully le ferroit et ceo prove duement serroit fait de luy come de traitour au Roi et son Roialme. Nentmeins grevouse pleint fuist fait a nostre Seignur le Roi en cest present parlement qe diverses gentz nient eiantz consideration a dit defense sibien en les countees de Cestre, Lancastre et aillours en Engleterre ont faitz tielx assemblees en outrageouse nombre pur accomplir lour malice encontre la pees nostre Seignur le Roi sa corone et sa dignite et les leies de sa terre par quoi nostre Seignur le Roi en cest present parlement ad defendu a touz ses lieges sibien Seignurs come autres de quecunqe estat qils soient qe null face tielx assemblees, riot, ou rumour encontre la pees en nul manere, et si ascun tiel assemble soit comenceant a pluis tost qe Viscontz et autres ministres le Roi poent eut avoir conissance ove la force du countee et pais ou tiel cas aviegne mettent destourbance encontre tiel malice ove tout lour poair et preignent tielx meffesours et les mettent en prisone tanqe due execution de leie soit fait de eux et qe touz Seignurs et autres liges du Roialme soient entendantz et aidantz de tout lour force et poair as Viscontz et ministres avauntditz en tiel cas.-17 Richard II., cap. viii.

Item, whereas in the Parliament, holden at Westminster the fifth year of the reign of our Sovereign Lord the King that now is,-forasmuch as villaines and other offenders of late have risen by assemblies 
and outrageous number in divers parties of the realm against the King's dignity and his erown, and the laws of the land, it was straitly defended by the King to all manner of people, that none from henceforth should make, or begin again such riot or rumour, nor other like; and if any man did, and that duly proved, he should be taken as a traytor to the King and his realm. Nevertheless, a grievous complaint was made to our Sovereign Lord the King in this present Parliament, that diverse people not having consideration to the said defence, as well in the counties of Chester, Lancaster, and elsewhere in England, have made such assemblies in outrageous manner, to accomplish their malice against the King's peace, his crown, his dignity, and the laws of the land. Therefore, our Sovereign Lord the King in this present Parliament hath defended to all the liege people, as well lords as other, of whatsoever estate that they be, that none shall make such assemblies, riot or rumour against the peace in no wise; and if any such assembly be begun as soon as the sheriffs and other the King's ministers may thereof have knowledge, they, with the strength of the county and country, where such case shall happen, shall set disturbance against such malice with all their power, and shall take such offenders, and them put in prison till due execution of the law be of them made, and that all lords and other liege people of the realm shall be attending and aiding with all their strength and power to the sheriffs and ministers aforesaid. 
Scene VIII. Southwark.

Alarum and retreat. Enter CADE and all his rabblement.

Cade. Up Fish Street! down Saint Magnus' Corner! kill and knock down! throw them into Thames! [Sound a parley.] What noise is this I hear? Dare any be so bold to sound retreat or parley, when I command them kill ?

Enter Buckingham and old Clifford, attended.

Buck. Ay, here they be that dare and will disturb thee:

Know, Cade, we come ambassadors from the king Unto the commons whom thou hast misled; And here pronounce free pardon to them all That will forsake thee and go home in peace.

I think the verb 'disturb' in this passage signifies to hinder, prevent, or oppose, and in this statute the word disturbance evidently signifies hindrance or opposition. Cade and his rabblement, who were acting in a riotous manner, and committing a breach of the peace, were disturbed or opposed by Buckingham and Clifford, who came as ambassadors from the King, and this statute enacts that the King's ministers shall set disturbance against 
DEFEND.

rioters and all others offending against the peace.

Hero. God defend the lute should be like the case.

Much Ado About Nothing, Act ii. Sc. 1.

In this and some other ancient statutes, the verb defend signifies to prohibit or forbid, and it is used in that sense by Hero.

Edmund. As for the mercy

Which he intends to Lear and to Cordelia, The battle done, and they within our power, Shall never see his pardon; for my state Stands on me to defend, not to debate.

Lear, Act v. Sc. 1.

I think Edmund may play upon the word, using it in its ordinary sense, and also in the sense in which it is used in several of the ancient statutes, including 3 Edward I, cap. xxxiv.; 1 Richard II., cap. IV.; and 2 Richard II., cap v., signifying to command.

Pur ceo qe plusours ount sovent trove en counte controveures, dont discorde ou manere de discord ad este sovent entre le Roi et son people ou ascuns hautes hommes de son roialme; est defendu pur le 
damage qe ad este, et unquore en purreit avenir, que desere en avant nul ne soit si hardy de dire, ne de counter nul faux novel, ou controveure, dount nul discorde, ou desclandre, puisse surdre contre le Roi et son people, ou les hautes hommes de son roialme; et qi le fra, soit pris et detenuz en prisone, jesques a taunt qil eit trove en Court celuy, dount le poeple (la parole?) serra move.-3 Edward I., cap. xxxiv. See also 2 Richard II., stat. 1, cap. v.; 12 Richard II., cap. xi.

Forasmuch as there have been oftentimes found in the country devisors of tales whereby discord, or occasion of discord, hath many times arisen between the King and the people, or great men of this realm; for the damage that hath and may thereof ensue, it is commanded that from henceforth none be so hardy to tell or publish any false news or tales whereby discord, or occasion of discord or slander, may grow between the King and his people, or the great men of the realm; and he that doth so shall be taken and kept in prison until he hath brought him into the court which was the first author of the tale.

The 2 Richard II., cap. v., is merely a repetition of this statute and in the same words.

Mal. She returns this ring to you, sir: you might have saved me my pains, to have taken it away yourself. She adds, moreover, that you should put your lord into a desperate assurance she will none of him: and one thing more, that you be never 
so hardy to come again in his affairs, unless it be to report your lord's taking of this. Receive it so. Twelfth Night, Act ii. Sc. 2.

Oliver. I'll tell thee, Charles: it is the stubbornest young fellow of France, full of ambition, an envious emulator of every man's good parts, a secret and villanous contriver against me, his natural brother. As You Like It, Act i. Sc. 1.

Coke, in his exposition of the 2 Richard II., cap. v., gives this signification of the word controveurs: 'devisors or inventors of their own head,' and it is perhaps worthy of consideration whether Oliver does not use the word in this sense.

Dem. You spend your passion on a misprised mood :

I am not guilty of Lysander's blood; Nor is he dead, for aught that I can tell.

Midsummer Night's Dream, Act iii. Sc. 2.

Obe. What hast thou done? thou hast mistaken quite

And laid the love-juice on some true-love's sight:

Of thy misprision must perforce ensue Some true love turn'd and not a false turn'd true. Midsummer Night's Dream, Act iii. Sc. 1. 
Friar. There is some strange misprision in the princes.

Bene. Two of them have the very bent of honour; And if their wisdoms be misled in this, The practice of it lives in John the bastard, Whose spirits toil in frame of villanies. Much Ado About Nothing, Act iv. Sc. 1.

The word misprision in these passages signifies a mistaking, in which sense it is used in some of the ancient statutes:

Item, est assentu \& establi qe par mesprision du clerc en quecunque place qe ce soit ne soit proces anientiz ne discontinues par mesprendre en escrivant un letre ou un silable tropp ou trop poi ; mes si tot qe la chose soit aperceu par chalenge du partie ou en autre manere soit hastivement amende en due forme sanz doner avantage a partie qe ce chalenge par cause de tiel mesprision.-14 Edward III., stat. 1, cap. vi.

Item, it is assented, that by the misprision of a clerk in any place, wheresoever it be, no process shall be annulled or discontinued by mistaking in writing one syllable, or one letter too much or too little; but as soon as the thing is perceived, by challenge of the party, or in other manner, it shall be hastily amended in due form, without giving advantage to the party that challengeth the same because of such misprision.

Item, ordeigne est \& establie qe les Justices du 
Roy devaunt queux ascune mesprision ou defaute soit ou serra trove soit il en ascun recordes \& processes qore sount ou serrount pendantz devaunt eux sibien par voie derrour come autrement ou en lez retournez dicelles faitz ou affairez par viscountz, coroners, baillifs des fraunchises, ou autres qeconqes par mesprision des clerks dascuns des ditz Courtz du Roi ou par mesprision des viscountz, soutzviscountz, coroners, lour clercs ou autres officers, clercs, ou ministres qeconqes en escrivant un lettre ou un silable trop ou trop poie aient poair demander tielx defautes \& misprisions solonc lour discretion, \& par examination ent par les ditz Justices aprendre ou lour semblera bosoignable. Purveu qe cest estatut ne se extende as recordes \& processes es parties de Gales ne as recordes \& processes dutlagaries, des felonies \& tresons \& les dependantz dicelles.8 Henry VI., cap. xv.

Item, it is ordained and established, that the king's justices, before whom any misprision or default is or shall be found, be it in any records and processes which now be or shall be depending before them, as well by way of error as otherwise, or in the returns of the same, made or to be made by sheriffs, coroners, bailiffs of franchises, or any others, by misprision of the clerks of any of the said courts of the king, or by misprision of the sheriffs, undersheriffs, coroners, their clerks, or other officers, clerks, or other ministers whatsoever, in writing one letter or one syllable too much or too little, shall have power to amend such defaults and misprisions ac- 
cording to their discretion, and by examination thereof by the said justices, to be taken where they shall think needful. Provided that this statute do

1 not extend to records and processes in the parts of Wales, nor to the processes and records of outlawries of felonies and treasons, and the dependence thereof.

Achil. 'Tis done like Hector; but securely done, A little proudly, and great deal misprizing The knight opposed.

Troilus and Cressida, Act iv. Sc. 5 .

Countess. This is not well, rash and unbridled boy,

To fly the favours of so good a king;

To pluck his indignation on thy head

By the misprising of a maid too virtuous

For the contempt of empire.

All's Well that Ends Well, Act iii. Sc. 2.

Oliver. Yet he's gentle, never schooled and yet learned, full of noble device, of all sorts enchantingly beloved, and indeed so much in the heart of the world, and especially of my own people, who best know him, that I am altogether misprised. As You Like It, Act i. Sc. 1.

Hero. O god of love! I know he doth deserve As much as may be yielded to a man: But Nature never framed a woman's heart Of prouder stuff than that of Beatrice; Disdain and scorn ride sparkling in her eyes, 
Misprising what they look on, and her wit Values itself so highly that to her All matter else seems weak : she cannot love, Nor take no shape nor project of affection, She is so self-endeared.

Much Ado about Nothing, Act iii. Sc. 1.

Cel. Young gentleman, your spirits are too bold for your years. You have seen cruel proof of this man's strength: if you saw yourself with your eyes or knew yourself with your judgment, the fear of your adventure would counsel you to a more equal enterprise. We pray you, for your own sake, to embrace your own safety and give over this attempt.

Ros. Do, young sir; your reputation shall not therefore be misprised: we will make it our suit to the duke that the wrestling might not go forward. As You Like It, Act i. Sc. 2.

In these passages it evidently signifies contempt or undervaluing.

Misprisio (says Coke) ' cometh of the word mes, pris, which properly signifieth neglect or contempt; for mes in composition in the French signifieth mal, as mis doth in the English tongue; as mischance, for an ill chance; and so mesprise is ill apprehended or known. In legal understanding it signifieth when one knoweth of any treason or felony and concealeth it; this is misprision, so called because the knowledge of it is an ill knowledge to him, in respect of the 
severe punishment for not revealing of it; for in case of misprision of high treason he is to be imprisoned during his life, to forfeit all his goods, debts, and duties for ever, and the profits of his lands during his life; and, in case of felony, to be fined and imprisoned.-3 Inst., cap. iii.

Misprision is twofold: one is crimen omissionis, of omission, as in concealment or not discovery of treason or felony; another is crimen commissionis, of commission, as in committing some heynous offence under the degree of felony.-3 Inst., cap. lxv.

Misprision is included in every treason or felony, and is where any one hath committed treason or felony the king may order that he shall be indicted for misprision only.-Wood's Institute, 2 ed. 406.

Oli. Sir, I bade them take away you.

Clo. Misprision in the highest degree! Lady, cucullus non facit monachum; that's as much to say as I were not motley in my brain. Good madonna, give me leave to prove you a fool.

Twelfth Night, Act i. Sc. 5.

Coke says, 'compassings or imaginations against the King by word, without an overt act, is a high misprision.'-3 Institute, cap. $1 \mathrm{xv}$. But although the clown here speaks of misprision in the highest degree, I think he plays upon the word, using it also in the sense of contempt. 
Ber. I cannot love her, nor will strive to do't. King. Thou wrong'st thyself, if thou shouldst strive to choose.

Hel. That you are well restored, my lord, I'm glad:

Let the rest go.

King. My honour's at the stake; which to defeat, I must produce my power. Here, take her hand, Proud scornful boy, unworthy this good gift;

That dost in vile misprision shackle up

My love and her desert; that canst not dream,

We, poising us in her defective scale,

Shall weigh thee to the beam; that wilt not know,

It is in us to plant thine honour where

We please to have it grow. Check thy contempt. All's Well that Ends Well, Act ii. Sc. 3.

And the King also probably uses it in a double sense, signifying wrong or false imprisonment, because it is connected with the adjective 'vile' and the verb 'shackle,' and also signifying contempt, with which word it is connected in this passage.

North. Yea, my good lord. Those prisoners in your highness' name demanded, Which Harry Percy here at Holmedon took, Were, as he says, not with such strength denied As is delivered to your majesty; 
Either envy, therefore, or misprision

Is guilty of this fault and not my son.

1 Henry $I V$., Act i. Sc. 2.

I think Northumberland uses the word in the sense of mistake or neglect.

Kent. Is not this your son, my lord?

Glou. His breeding, sir, hath been at my charge: I have so often blushed to acknowledge him, that now I am brazed to it.

Lear, Act i. Sc. 1.

Hamlet. Leave ringing of your hands: peace! sit you down,

And let me wring your heart : for so I shall, If it be made of penetrable stuff, If damned custom have not braz'd it so That it is proof and bulwark against sense.

Act iii. Sc. 4.

Item, pur ceo qe les arrousmyths font plusours testes de setes \& quarelx defectifs nient bien ne loialment ne deffensablement a grant perill \& desceit du people et de tout le Roialme, ordeignez est \& establiz qe toutz les testes de setes \& quarels desore enavaunt affairs soient boilles ou brases \& dures a la point dasser, et si ascuns des ditz arrousmythes les facent a contrarie qils forsfacent toutes 
tielx testes \& quarels au Roy \& soient emprisonez \& ent facent syn a la volunte du Roy. Et qe chescun teste des setes \& quarels soit seigne dune signe de celuy qe le fist. Et eient les justices de la pees en chescun counte dEngleterre \& auxi les mairs, viscountes \& baillifs des citees \& burghs deinz mesmes les citiees \& burghs poiar denquer des toutz tieux faux fesours de testes \& quarels \& de les punir par manere come dessuis est dit.

7 Henry IV., cap. vii.

Item, because the arrow-smiths do make many faulty heads of arrows and quarels defective, not well, nor lawful, nor defensible, to the great jeopardy and deceit of the people, and of the whole realm; it is ordained and established, that all the heads of arrows and quarels after this time to be made shall be well boiled or brased and hardened at the point with steel; and if any of the said smiths do make the contrary they shall forfeit all such heads and quarels to the king, and shall be also imprisoned and make a fine at the king's will ; and that every arrow-head and quarel be marked with the mark of him that made the same. And the justices of peace in every county of England, and also the mayor and sheriffs, and bailiffs of cities and boroughs, within the same cities and boroughs, shall have power to enquire of all such deceitful makers of heads and quarels, and to punish them as afore is said.

Malcolm.

With this there grows

In my most ill-composed affection such 
A stanchless avarice that, were I king, I should cut off the nobles for their lands, Desire his jewels and this other's house : And my more-having would be as a sauce To make me hunger more; that I should forge Quarrels unjust against the good and loyal, Destroying them for wealth.

Malcolm.

What I am truly,

Is thine and my poor country's to command: Whither indeed, before thy here-approach, Old Siward, with ten thousand warlike men, Already at a point, was setting forth.

Now we'll together: and the chance of goodness Be like our warranted quarrel! Why are you silent?

Macbeth.

Malcolm says, 'I should forge quarrels unjust,' and this statute speaks of 'deceitful makers of heads and quarels;' and he may use the word in a double sense, because the verbs 'forge' and 'warrant' might be applied to the quarrels mentioned in this statute, or at least to their heads, which were boiled or brased, and hardened at the points with steel; and the word quarrel may be accepted in the sense in which it is used in the 1 Richard II., cap. iv., which is in these words :- 
Item, ordeine est \& establi \& le Roi nostre Seignour defend estroitement qe nul conseiler, officer ou servant nautre ovesqe lui nascun autre persone du Roialme dEngleterre de quel estate ou condition qils soient nenpriegnent desore ou susteignent ascun querell par mayntenance en pais ou aillours sur grevouse peyne, cest assavoir les ditz conseillers \& grantz officers du Roi sur peyne qe serra ordeigne par le Roi memes del avys des Seignours de Roialme \& les autres meyndres officers \& servantz le Roi sibien en Lescheqer \& en toutes ses autres Courtes \& places come de sa propre meignee sur peine de perdre lour offices \& services \& destre emprisonez \& dilloeqes estre reintz a la volunte le Roi chescun de ceux solonc sez degre, estat \& desert \& toutz autres persones parmy le Roialme sur la dite peyne denprisonement \& destre reintz come les autres desus ditz.

Item, it is ordained and stablished, and the King our Lord straitly commandeth, That none of his counsellors, officers, or servants, nor any other person within the Realm of England, of whatsoever estate or condition they be, shall from henceforth take nor sustain any Quarrel by maintenance in the country, nor elsewhere, upon a grievous pain: that is to say, the said counsellors and the king's great officers, upon a pain which shall be ordained by the king himself, by the advice of the Lords of his realm; and other less officers and servants of the King, as well in the Exchequer, and all his other courts and places, as of his own meiny, upon pain to 
lose their offices and services, and to be imprisoned, and then to be ransomed at the king's will, every of them according to their degree, estate, and desert; and all other persons through the realm upon pain of imprisonment, and to be ransomed as the other aforesaid.

Item, si home relessa a un auter touts manners de quarrels ou touts controversies ou debates enter eux, etc. quaere, a quel matter et a quel effect tiels parols soy extendent, \&c. - Litt., sec. 511.

The meaning of the word quarrel used in this statute is thus described by Coke:-

This word querela is derived a querendo, unde etiam querens who is the plaintiff, and quarrels, controversies, and debates, are synonima and of one and the same signification.-Edward Altham's Case, 8 Rep. 153. And in another part of the same Report, Coke says, as to this word querelas it is to be known that quarrels extend not only to actions as well real as personal, as it is held in $9 \mathrm{E}$. 4. 44. a., but also to causes of action and suits, as it is held in 39 H. 6. 9. b. So that by release of all quarrels, not only actions depending in suit, but causes of action and suit also are released.-Co. Litt. 292. a.

Old. L. Hearts of most hard temper Melt and lament for her.
Anne.
O, God's will! much better She ne'er had known pomp: though 't be temporal, 
Yet, if that quarrel, fortune, do divorce It from the bearer, 'tis a sufferance panging As soul and body severing.

$$
\text { Henry VIII., Act ii. Sc. } 3 .
$$

Shakespeare may play upon the word quarrel in this passage, using it in the sense in which it is used in the 7 Henry IV., cap. vii., signifying a dart which was discharged from a cross-bow, and in the sense in which it is used in the 1 Richard II., cap. iv., signifying a dispute or controversy; he also speaks here of hearts of most hard temper, and seems to play upon the word temporal. The word temper was applicable to heads of quarrels which had been hardened at the points, as it was to Othello's 'sword of Spain, the ice-brook's temper.' Shakespeare also speaks of 'that quarrel, fortune, divorcing pomp from the bearer;' and in the same play, Act ii. Sc. 1, Buckingham says :-

Go with me, like good angels, to my end; And, as the long divorce of steel falls on me, Make of your prayers one sweet sacrifice, And lift my soul to heaven.

Sal. It seems you know not, then, so much as we: 
The Cardinal Pandulph is within at rest, Who half an hour since came from the Dauphin, And brings from him such offers of our peace As we with honour and respect may take, With purpose presently to leave this war.

Bast. He will the rather do it when he sees Ourselves well sinewed to our defence.

Sal. Nay, it is in a manner done already;

For many carriages he hath dispatch'd To the sea-side, and puts his cause and quarrel To the disposing of the cardinal: With whom yourself, myself and other lords, If you think meet, this afternoon will post To consummate this business happily.

$$
\text { King John, Act v. Sc. } 7 .
$$

Bates. He may show what outward courage he will : but I believe, as cold a night as 'tis, he could wish himself in Thames up to the neck; and so I would he were, and I by him, at all adventures, so we were quit here.

K. Hen. By my troth, I will speak my conscience of the king: I think he would not wish himself any where but where he is.

Bates. Then I would he were here alone; so should he be sure to be ransomed, and a many poor men's lives saved.

$K$. Hen. I dare say you love him not so ill, to wish him here alone, howsoever you speak this to feel other men's minds: methinks I could not die 
any where so contented as in the king's company; his cause being just and his quarrel honourable. Henry $V_{.}$, Act iv. Sc. 1.

I think the word quarrel is used by Salisbury and King Henry in this legal sense, and the reader will see that they both connect the word quarrel with the word cause; and although this word quarrel is generally and frequently used by Shakespeare to signify a brawl or petty fight, or scuffle :-

Olivia. This practice hath most shrewdly pass'd upon thee;

But when we know the grounds and authors of it, Thou shalt be both the plaintiff and the judge Of thine own cause.

Fabian. Good madam, hear me speak, And let no quarrel nor no brawl to come Taint the condition of this present hour, Which I have wonder'd at.

Twelfth Night, Act v. Sc. 1.

It may sometimes be considered doubtful in which sense it is used.

Kent. They summon'd up their meiny, straight took horse,

Commanded me to follow, and attend

The leisure of their answer.

Lear, Act ii. Sc. 4. 
Meiny, menagium ; French, mesnie; as the King's meiny; that is, the King's family or household servants. (Cowell.) This word is also used in 27 Edward III., cap. viii.

Item, avoms ordeigne \& establi, que lez Mairs \& les Counstables de lestaples eient jurisdiction \& conisaunce deinz lez villez ou lestaples serrount \& en lez suburbes dicels gentez \& dez toutz maners choses tochauntes lestaple, \& que touts merchants beignants a lestaple lour servants \& meignee en lestaple soient mesnes per la ley merchant de toutes choses touchants lestaple, \& nemy a la comune ley de la terre, ne per usage dez Citees, Burghs, nautres Villes, \&c.

Item, we have ordained and established, That the mayor and constables of the staple shall have jurisdiction and cognisance within the towns where the staples shall be, of people, and of all manner of things touching the staples. And that all merchants coming to the staple, their servants and meiny in the staple shall be ruled by the law-merchant, of all things touching the staple, and not by the common law of the land, nor by usage of cities, boroughs, or other towns, \&c.

Morton.

It was your presurmise, That, in the dole of blows, your son might drop. 2 Henry IV., Act i. Sc. i.

Anne. I mean, Master Slender, what would you with me? 
Slen. Truly, for mine own part, I would little or nothing with you. Your father and my uncle hath made motions: if it be my luck, so ; if not, happy man be his dole!

Merry Wives of Windsor, Act iii. Sc. 4.

King Henry. If we are mark'd to die, we are enow

To do our country loss; and if to live,

The fewer men, the greater share of honour.

Henry V., Act iv. Sc. 3.

Ber. Pardon, my gracious lord : for I submit My fancy to your eyes: when I consider What great creation and what dole of honour Flies where you bid it, I find that she, which late Was in my nobler thoughts most base, is now The praised of the king; who, so ennobled, Is as 'twere born so.

All's Well that End's Well, Act ii. Sc. 2.

Forasmuch as within these few years now last past there hath been levied, perceived and taken by certain of the officers of the Admiralty, of such merchants and fishermen, as have used and practised the adventures and journeys into Iceland, Newfoundland, Ireland and other places commodious for fishing and the getting of fish, in or upon the seas or otherwise, by way of merchandise in those parts, divers great exactions, as sums of money, doles or shares of fish and such other like things, to the great 
discourgement and hindrance of the same merchants and fishermen, and to no little damage to the whole commonweal: and whereof also great complaints have been made and informations also yearly to the King's Majesty's most honourable council: For reformation whereof, and to the intent also that the said merchants and fishermen may have occasion the rather to practise and use the same trade of merchandise and fishing freely without any such charges or exactions as is before limited, whereby it is to be thought that more plenty of fish shall come into this realm, and thereby to have the same at more reasonable price. Be it therefore enacted that neither the admiral nor any officer or minister, officers or ministers of the Admiralty for the time being, shall in any wise hereafter exact, receive or take by himself, his servant, deputy, servants or deputies, of any such merchant or fisherman, any sum or sums of money, doles or shares of fish, or any other reward, benefit, or advantage whatsoever it be, for any licence to pass this realm to the said voyages or any of them; nor upon any respect concerning the said voyages or any of them.-2 \& 3 EdwardVI., cap. vi.

In this statute and in these passages the word dole signifies a share or portion. Dole and share are reciprocal terms, and the reader will see that Bertram uses the expression 'dole of honour,' and King Henry the expres- 
sion 'share of honour.' Dole, dola, a Saxon word, says Cowell, signifying as much as pars or portio in Latin. 'It hath of old been attributed to a meadow, and still so called, as dole-meadow-4 Jac. I., cap. xl._because divers persons had shares in it.' We still retain the word to signify a share, as to deal a dole: ' he dealt his dole among so many poor people,' that is, he gave every one a share or part.

Val. How now, sir? what are you reasoning with yourself?

Speed. Nay, I was rhyming: 'tis you that have the reason.

Val. To do what?

Speed. To be a spokesman for Madam Silvia.

Val. To whom?

speed. To yourself: why, she wooes you by a figure.

Val. What figure?

Speed. By a letter, I should say.

Val. Why, she hath not writ to me?

Speed. What need she, when she hath made you write to yourself? Why, do you not perceive the jest.

Val. No, believe me.

Speed. No believing you, indeed, sir. But did you perceive her earnest?

Two Gentlemen of Verona, Act ii. Sc. 1. 
The preamble of the 32 Henry VIII., cap. xxii., referring to the 26 Henry VIII., cap. iii., recites :-

That your Majesty, your heirs and successors, kings of this realm, for more augmentation and maintenance of the royal estate of your imperial crown and dignity of supreme head of the Church of England, should yearly have, take, perceive and enjoy, united and knit to your imperial crown for ever, one yearly rent or pension, amounting to the value of the tenth part of all the revenues, rents, farms, \&c.

In several of the ancient statutes the verb 'perceive' signifies to receive or take. Speed seems to use the verb first in its ordinary sense: 'Do you understand or see with your mind the jest?' And afterwards in the sense in which it is used in these statutes: 'Did you receive or take her earnest?' And he may use it in a double sense, as he seems to use the word earnest. The Latin from which this word is derived includes, of course, both senses: percipio, per and capio; to take possession of, seize, occupy, to get, obtain, receive, perceive, to observe, \&c. The preamble of the 2 and 3 Edward VI., cap. vi., speaks of 
divers doles or shares of fish having been perceived or taken; and afterwards the statute forbids any officer to receive or take any doles or shares of fish for licence to pass this realm, \&c.

END OF THE FIRST PART. 



\section{APPENDIX.}

\section{The 'Standard,' London, May 17, 1869.}

THE number of books which have been written in defence, illustration, elucidation, and explanation of Shakespeare is so great as to form a complete library; and Mr. W. L. Rushton has now added to the number in a handy little volume entitled Shakespeare Illustrated by Old Authors, in which single passages of the great bard are taken, and brought side by side with other passages of prose and verse from English and foreign classics, which seem to throw light on doubtful or curious words, phrases, or customs alluded to in the text. Some of these illustrations are exceedingly apt, and the scholar and the critic will find among them much pleasant reading. The second part of his little book is devoted to an examination of the language of Shakespeare's last will and testament, and is even more curious and interesting than the preceding chapters. Taken as a whole the plan of this little handbook is well conceived and well executed. The passages selected by the author from preceding or contemporaneous writers will throw light on many an obscure passage, and the light will be of 
a far more genuine kind than that which springs from the fanciful and ingenious guesses of modern commentators. 'Puttenham's Arte of English Poesie,' with which Shakespeare was clearly well acquainted, is a book which to previous critics seems to have been all but unknown.

The 'Law Magazine and Review,' May, 1869.

Mr. Rushton has proved himself an able legal commentator of the works of Shakespeare. In addition to the above little book of comparison he has contributed largely to illustrate by old authors the language used by the immortal bard in his plays and poems. In this way he has satisfactorily explained many obscure expressions of doubtful meaning, and has offered explanations and suggestions of his own for the consideration of his readers. His 'Shakespeare a Lawyer' and 'Shakespeare's Legal Maxims' unmistakably show that if Shakespeare was not at one time connected with the law, as has been attempted to be shown by some of his biographers, yet by some unaccountable means he acquired extensive familiarity with technical legal phraseology. Shakespeare's plays abound with instances of much more than ordinary knowledge of law terms for a civilian, and in order to use these in the way he did, his acquaintance with the written and unwritten law of his period, combined with a tolerable display of legal jargon, must have been remarkable. 
Be this as it may, Mr. Rushton's comments in the little book we have before us are only directed to show Shakespeare's general knowledge of the law relating to real and personal estate, by comparing testamentary language found in his plays and poems chiefly with the work of a contemporary author. Swinburne's 'Briefe Treatise of Testaments and Last Willes,' the text book referred to, was published in 1590, when our hero was about twenty-six years of age, and just about the time when the first of his plays appeared.

The work of research has been more into Shakespeare than into the law generally, as most of the comparisons are to be found in the text book just mentioned, which it is more than probable, from the similarity of expressions used, was a valuable book of reference in Shakespeare's library.

LONDON : PRINTED BY SPOTTISWOODE AND CO., NBW-STEBRT SQUATS AND PARLIAMIENT BTEEET 


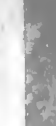

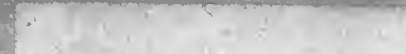

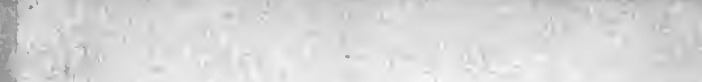
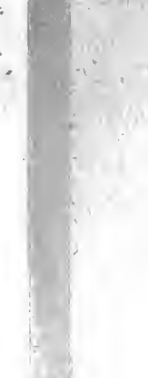

.

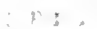

ist is is i

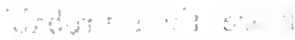

Eisi.

a $\therefore \cdots$

S. 


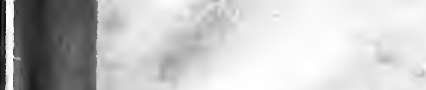

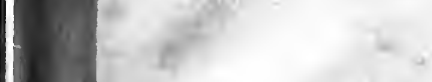
(1) 


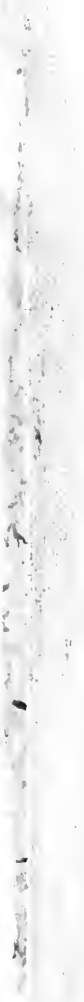




\section{PLEASE DO NOT REMOVE CARDS OR SLIPS FROM THIS POCKE}

\section{UNIVERSITY OF TORONTO LIBRARY}

PR

3028

R78

1870

v.1

\section{Rushton, rilliam Lowes}

Shakespeare illustrated the Lex Scripta 
